\title{
Positioning the Electric Utility to Build Information Infrastructure
}

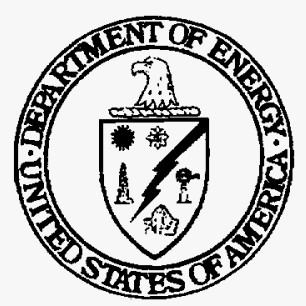

November 1994

\section{U.S. DEPARTMENT OF ENERGY Office of Energy Research Office of Scientific Computing} Washington, DC 20585 



\section{DISCLAIMER}

This report was prepared as an account of work sponsored by an agency of the United States Government. Neither the United States Government nor any agency thereof, nor any of their employees, make any warranty, express or implied, or assumes any legal liability or responsibility for the accuracy, completeness, or usefulness of any information, apparatus, product, or process disclosed, or represents that its use would not infringe privately owned rights. Reference herein to any specific commercial product, process, or service by trade name, trademark, manufacturer, or otherwise does not necessarily constitute or imply its endorsement, recommendation, or favoring by the United States Government or any agency thereof. The views and opinions of authors expressed herein do not necessarily state or reflect those of the United States Government or any agency thereof. 


\section{DISCLAIMER}

Portions of this document may be illegible in electronic image products. Images are produced from the best available original document. 


\section{ACKNOWLEDGMENTS}

Two papers undertaken as a "summer study" requested by the Office of Energy Research of the U.S. Department of Energy compose the main part of this book. I appreciate the encouragement of Dr. David Nelson, Associate Director of the Office of Energy Research, and Stuart Goldstein, Special Assistant to the Director. The project officer for DOE was John Cavallini, Acting Associate Director of the Office of Scientific Computing, and my work was supervised for Lawrence Berkeley Laboratory by Dr. Stewart Loken, Director of the Information and Computer Sciences Division. I also appreciate the help and encouragement of Robert J. Aiken of Lawrence Livermore National Laboratory and Dorthy Akins, Cynthia Coolahan, and Frank Olken of Lawrence Berkeley Lab.

Useful references and comments were provided by Eric Ackerman, Dean Toni Carbo Bearman, Dr. Stephen N. Brown, James T. Bruce, III, Esq., Sidney Cimmet, Esq., Ted Coombes, J. Kathy Fogel, Esq., John Glaser, Adam M.

Golodner, Esq., Professor Susan G. Hadden, Steve Johnson, Richard Larochelle, John C. McClure, Esq., Paul Nordstrom, Esq., Howard Rausch, William J. (Billy) Ray, Ron Skelton, Elizabeth Thomas, Esq., Wallace F. Tillman, Esq., W. Randolph Young, Esq., and William C. Weeden, Esq.

All the conclusions and any mistakes are my own.

Steven R. Rivkin 



\section{EXECUTIVE SUMMARY}

In two particular respects (briefly investigated in this study from a lawyer's perspective), electric utilities appear uniquely well-positioned to contribute to the National Information Infrastructure (NII).

First of all, utilities have legal powers derived from their charters and operating authorities, confirmed in their rights-of-way, to carry out activities and functions necessary for delivering electric service. These activities and functions include building telecommunications facilities and undertaking information services that have become essential to managing electricity demand and supply. Now that the reach of such activities and functions extends to the residence, all types of U.S. utilities-investor-owned (including holding companies regulated by the U.S. Securities \& Exchange Commission), municipal, and cooperative-are similarly enabled to make a strategic contribution to the NII.

The economic value of the efficiencies made possible by telecommunications and information could be substantial. How great remains to be established, but by many estimates electric utility applications could fund a significant share of the capital costs of building the NII.

Though utilities' legal powers to pursue such efficiencies through telecommunications and information appear beyond dispute, it is likely that the effort to do so will produce substantial excess capacity. Who will benefit from this excess capacity is a potentially contentious political question that demands early resolution. Will this windfall go to the utility, the customer, or no one (because of political paralysis), or will there be some equitable and practical split?

A second aspect of inquiry here points to another contemporary issue of very great societal importance that could very well become the platform on which the first question can be resolved fortuitously-how to achieve universal telecommunications service. This issue of universal service, made urgent by the imminent substitution in telecommunications of competition for regulated monopolies, was a key concern in the unsuccessful effort to reform telecommunications in the 103rd Congress. Though the potential of electric utilities to provide telecommunications services was recognized in proposed legislation, the fact that electric utilities already serve 95 percent of American homes (a percentage point above telephone companies) and the likely requirement that all these homes will need access to advanced telecommunications to manage energy have yet to be factored into the debates.

In the effort to fashion the NII that will now continue, ways and means to maximize the unique potential contribution of electric utilities to meeting important social and economic needs-in particular, universal service-merit priority attention. 


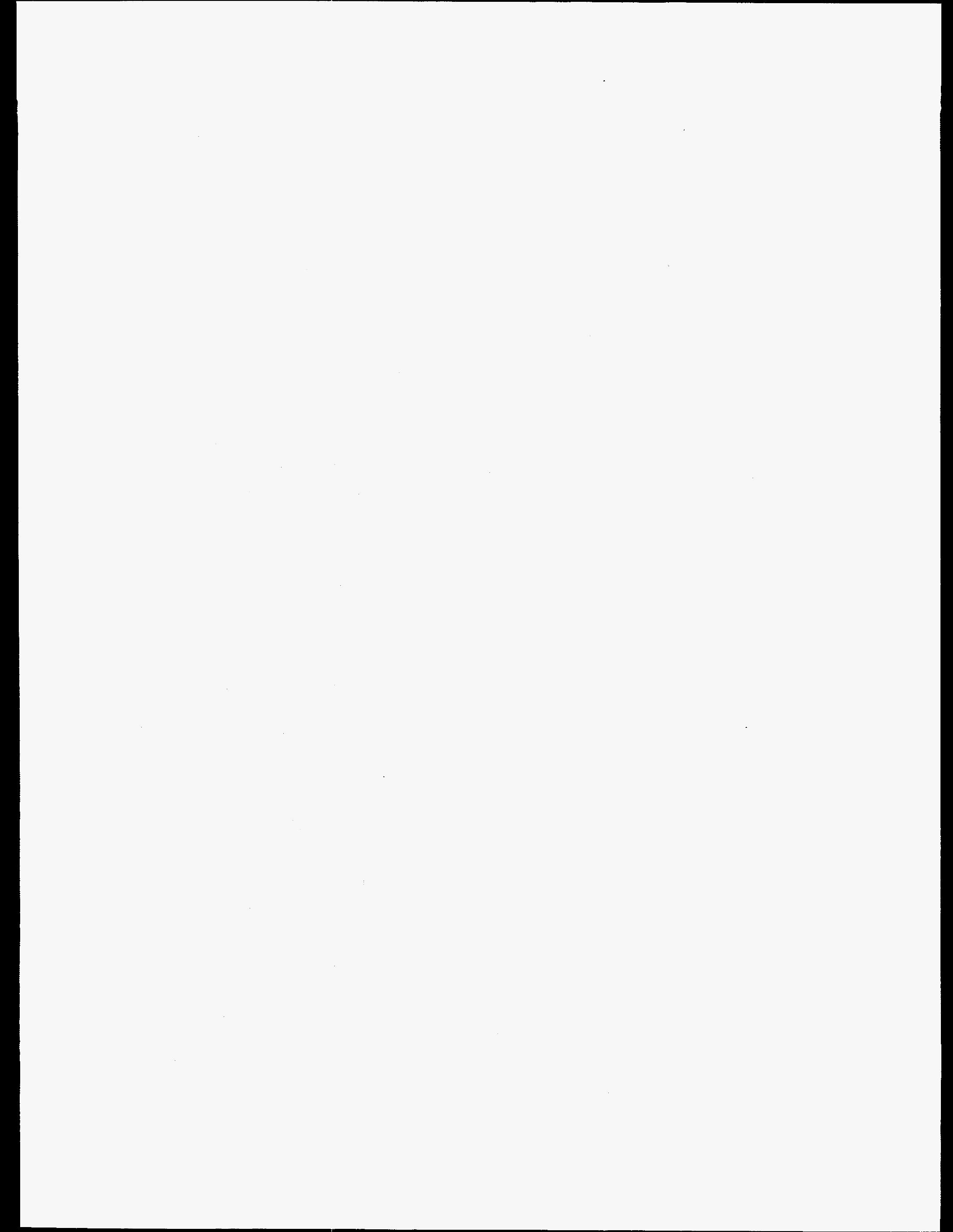




\section{CONTENTS}

Acknowledgments ............................................................................ ii

Executive Summary ............................................................................................ v

Abbreviations ........................................................................................... ix

Chapter 1. Introduction ..................................................................... 1-1

1.1. Broad Enabling Authority ...................................... 1-1

1.2. Political Relationships ............................................ 1-2

1.3. Dealing with a Windfall ......................................... 1-3

1.4. The Registered Holding Companies (RHCs): A Case in Point ...................................... 1-4

1.5. Managing the Windfall to Ensure Universal Service ....................................................................... 1-4

Chapter 2: Do Electric Utilities Have Legal Authority to Build the National Information Infrastructure? ...... 2-1

2.1. Introduction 2-2

2.2. Legal Authorities of Investor-Owned Utilities

2.3. Legal Authorities of Registered Holding Companies

2.4. Legal Powers of Municipal Utilities

2.5. Legal Powers of Rural Electric Cooperatives

2.6. Conclusions.

Chapter 3: How Electric Utilities Can Contribute to Universal Telecommunications Service

3.1. Congress Strives to Assure Universal Service

3.2. Congress Starts to Recognize a Role for Utilities

3.3. Fitting Utilities into Universal Service

3.4. Utility Rate Incentives Can Assure Universal Service.

3.5. Telecommunications Reform Via a New Regulatory Compact

Chapter 4: A New Option for Telecommunications 



\section{ABBREVIATIONS}

$\begin{array}{ll}\text { CCLM } & \text { Customer-Controlled Load Management } \\ \text { co-op } & \text { consumer-owned utility } \\ \text { DSM } & \text { demand-side management } \\ \text { FCC } & \text { Federal Communications Commission } \\ \text { FERC } & \text { Federal Energy Regulatory Commission } \\ \text { IOU } & \text { investor-owned utility } \\ \text { LP\&L } & \text { Louisiana Power \& Light } \\ \text { MP\&L } & \text { Mississippi Power \& Light } \\ \text { municipal } & \text { government-owned utility } \\ \text { NII } & \text { National Information Infrastructure } \\ \text { NOPSI } & \text { New Orleans Public Service, Inc. } \\ \text { PUC } & \text { Public Utilities Commission } \\ \text { PUD } & \text { Public Utility District } \\ \text { PUHCA } & \text { Public Utility Holding Company Act } \\ \text { PURPA } & \text { Public Utilities Regulatory Policy Act } \\ \text { RCW } & \text { Revised Code of Washington (State) } \\ \text { REA } & \text { Rural Electrification Administration } \\ \text { RHC } & \text { registered holding company } \\ \text { SEC } & \text { U.S. Securities \& Exchange Commission } \\ \text { WPPSS } & \text { Washington Public Power Supply System }\end{array}$




\section{Chapter 1}

\section{INTRODUCTION}

This document investigates how electric utilities can be positioned to help build the National Information Infrastructure. In particular, two aspects of utilities' readiness and ability to participate in such an endeavor are examined: (1) Whether electric utilities have sufficient legal authority, in the first place, to build telecommunications infrastructure, and (2) whether electric utilities, for special reasons, can contribute to ensuring universal telecommunications service. (These questions are treated separately, in Chapters 2 and 3.)

The two topics were chosen because they have been the objects of confusion and uncertainty, which the author's professional experience over many years and insight as a lawyer may help illuminate. The timing of the effort proved to be less awkward than might have been expected, as when this project was undertaken bills were pending in Congress that could have clarified or resolved several important questions. In the end, the bills were not enacted, so no significant changes have been made in the legal context, and it is possible that some of the findings of this investigation might help to shape new bills next year that could promote a larger role for electric utilities than the legislation proposed in 1994.

The two inquiries of this investigation yielded conclusions that, rather surprisingly, can be linked to form a consistent and coherent perspective on how to build the National Information Infrastructure.

\subsection{Broad Enabling Authority}

Regardless of their form of ownership-investor-owned utility (IOU), registered holding company ( $\mathrm{RHC}$ ), government-owned utility (municipal), or consumer-owned utility (co-op) - power companies have ample legal authority in their charters and legislative grants to build telecommunications facilities that are necessary or (more generously stated) useful and convenient for running an electric utility. Technological and market imperatives have recently expanded the reach of utility telecommunications to the residence, and this expansion of functions provides compelling reasons for the utility's legal powers to expand to keep pace-so the utility can function as effectively under current conditions as was contemplated when its powers were first fashioned as much as 100 years ago. By this logic, the utility has legal authority to deploy switched broadband facilities to reach all of its customers' meters and electric appliances, which is required to run an electric company efficiently nowadays. (Examples extracted from case law and culled from the author's files during 15 years of advising power companies are presented in Chapter 2.)

So, the utilities have strong legal rights, if they are ready to make the case for them-i.e., that they need high-capacity, reliable telecommunications to reach all of their customers in real-time, and that they can't take a back seat operationally to other users by sharing telecommunications infrastructure the utility 
does not control. Thus utilities can readily substantiate they have the ability (1) to build switched broadband telecommunications facilities, and (2) provide information services related to energy management. Because of the potentially large economic benefits to be derived from using advanced telecommunications and information services, electric utilities have verifiable, legitimate, and immediate interests in two-way broadband connections with the ultimate user of electricity. ${ }^{1}$

Besides having existing legal authority, utilities have another advantage for establishing telecommunications infrastructure: they can readily pay for such efficiency-enabling facilities out of system revenues. Moreover, providing such services would require very little ramping up and therefore could become finaricially significant very soon. (The swift accumulation of savings could lead to sources of capital for building telecommunications plant that are potentially more reliable than the conventional alternative - video entertainment-that had predominated in plans for building information highways before electric utility applications arrived on the horizon.)

This is not to say that an ancient charter or grant of right-of-way cannot be questioned as a warrant to build a broadband fiber system today. There may very well be questions a court could spend a year or more raking over, but a modern legal interpretation of a utility's powers, in light of its expanding operations, would almost surely enable the utility to build facilities mandated by its operational needs and made possible by modern telecommunications techriology.

But note an additional factual corollary: the utility must enthusiastically enunciate its need to use modern telecommunications to the residence expressly to save energy and ameliorate the environment. In other words, there can be no ambiguity about the functional imperative of its need for information.

\subsection{Political Relationships}

Expansive traditional powers would give utilities an advantage if they choose to bargain for updated and enlarged operating authorities. That's what Entergy's New Orleans subsidiaries Louisiana Power \& Light (LP\&L) and New Orleans Public Service, Inc. (NOPSI), anticipate currently as they seek limited authority from the City Council to build facilities for a two-year energy management demonstration, without prejudice to the power company's contention that it already has ample legal authority to build the facilities anyway. The brottom line is that a municipality will be loath to incur the costs and burdens of challenging an investor-owned utility's initiative to build telecommunications facilities that enable it to serve its customers better.

The utilities may have an advantage, but not one without limits. For instance, municipal power companies are traditionally concerned that their stategranted legal authority to issue tax-exempt bonds will be questioned-especially since the Washington Public Power Supply System (WPPSS) fiasco invalidated

\footnotetext{
${ }^{1}$ See, for example, "Supply and Demand of Electric Power and the NII," in The Information Infrastructure: Reaching Society's Goals. A Report of the Information Infrastructure Task Force Committee on Applications and Technology, U.S. Department of Commerce, National Institute of Standards and Technology (September 1994), p. 25 ff. According to another authoritative and even more recent report, "Energy production and delivery will be tightly coupled with telecommunications and information services for the foreseeable future." (Business Opportunities and Risks for Electric Utilities in the National Information Infrastructure, Electric Power Research Institute [October 1994], p. v.)
} 
bonds that a court found had not been expressly authorized. But at least one state (Arkansas) has cured any potential deficiency in its cities' powers to build telecommunications by expressly granting legislative authority (to build cable television), and in another state (Washington) an effort was begun this year to enable public utility districts explicitly to install telecommunications facilities to be used primarily for load management, but with surplus capacity that could be leased to others on a nondiscriminatory basis.

Though such express legislative help would always be welcome (if achieved without weakening the municipal utility's implied powers), it may not be essential. For one thing, a municipal can bring a well-crafted petition for declaratory judgment to a state court asking for its interpretation of existing authority in the light of changing technology and markets. On the facts as they can be shown to have become, creative judges could have straightforward grounds to authorize utilities to enlarge their telecommunications functions.

\subsection{Dealing with a Windfall}

But a serious political problem accompanies the expanded powers of electric utilities-the problem of excess capacity. Excess capacity will be found both in a utility's telecommunications system and in its energy-management information services. Excess capacity could create windfalls by enabling utilities to migrate into rich and growing telecommunications markets like none they have recently known. Who would harvest those windfalls? The utility? The customers? Or, worst case, no one-if the utility lets the opportunities slip away or because political accommodation has failed?

It is often pointed out that a utility's near-term telecommunications needs will occupy only a small fraction of the bandwidth available in broadband telecommunications-as little as two percent according to claims asserted by Entergy's opponents in the controversy now raging before the New Orleans City Council (discussed in Chapter 2). ${ }^{2}$

Why should a utility be positioned to capture for itself and its shareholders the huge economic value of capacity in excess of utility needs that utility ratepayers have paid for? Judging from the transcript of the New Orleans proceeding, this is just the transfer of benefits feared by the City Council, which feels that the ratepayers are entitled to all the benefits from Entergy's telecommunications initiatives and suspects Entergy of preparing to stiff the ratepayer through federal preemption.

On the other hand, why shouldn't the utilities capture all the windfall for themselves? If they are ingenious enough to harness new telecommunications and information technology to save electricity and, presumably, help lower power bills and ameliorate the environment, shouldn't the utility have generous rewards for its insight and initiative? Wouldn't its becoming a new and potent player in telecommunications be ample benefit for society? Aren't the registered holding companies, for example, seeking their just deserts in trying to break out of what they regard as the straitjacket of the Public Utility Holding Company Act

\footnotetext{
${ }^{2}$ Actually, the 2 percent figure could be quite low for the bandwidth power companies could usefully employ in their power businesses today, especially once the retail market is launched. In any event, it will be innately meaningless from now on to consider telecommunications bandwidth in such a nickel-and-dime fashion, since fiber-optics have huge and virtually limitless capacities, already reaching a gigabit and beyond. Also, integrated digital transmissions will be inherently impossible to disaggregate by any quantitative standard, while data compression grows increasingly efficient and versatile.
} 
(see Section 1.4) by entering deregulated telecommunications and information markets as strong new competitors, on no more onerous footing than any rival?

Whatever the outcome of the holding companies' drive for legislative relief (which failed in 1994 but can be counted on to resume next year), it is obvious that how to distribute the windfall is the basic political issue. Obviously, too, that issue could be resolved either way or-better yet-by some equitable split down the middle.

\subsection{The Registered Holding Companies (RHCs): A Case in Point}

More than any other aspect of electric utilities' entry into telecommunications, the drive by the regulated holding companies to gain a legislative exemption from the Public Utility Holding Company Act has drawn the most attention in Washington over the past year, far above their 16 percent proportionate share of the national residential market. Provisions in the Senate bill would have given them most of what they want in the form of an exemption from regulation by the U.S. Securities \& Exchange Commission (SEC).

Likelihood of a legislative change aside, it is evident that the RHC position represents one polarity in how the telecommunications windfall might be handled. The RHCs proclaim they want all options open; i.e., to be free of regulation, with the RHCs being specifically authorized to engage in entrepreneurial businesses involving their telecommunications facilities and information capabilities.

So far, the SEC's response to the RHC initiative has been very low key. In February 1994, the Commission transmitted a staff proposal to the House for a legislative change that would qualify economically limited telecommunications investments approved by the Federal Communications Commission (FCC) for administrative exemption under the Holding Company Act because they meet the "functional relationship" test as "assets" of electric utilities. More recently, the SIEC has begun a comprehensive review of its jurisdiction that promises to examine the continued viability of the "integrated public utility" concept at the heart of the Act, in light of broad economic changes undermining the vertical integration in utility functions.

Passage would appear very unlikely of a blanket exemption for telecommunications investments before the SEC's internal review is completed. On the other hand, both of the paths the SEC has already opened hold some promise for RHCs. First of all, building telecommunications facilities and conducting energy-related demand-side management do logically have clear functional relationships to running an electric utility in general (thereby meeting the existing statutory test). And second, as utilities become dis-aggregated, adding telecommunications to the distribution functions can readily effectuate and fortify many of the new entities now emerging.

\subsection{Managing the Windfall to Ensure Universal Service}

Whether or not the RHCs win the exemption they have so vigorously sought, the disposition of the windfall will remain a vital issue, if only for the huge remainder of the retail electricity market. The 1994 telecommunications reform bills tapped a vein of surprisingly intense national concern over how to 
assure universal telecommunications service in a newly competitive market, and no final answer has yet been found. Using the windfall specifically to accomplish universal service would appear to be a well-timed expedient to meet a deeply felt national need.

As discussed in Chapter 3, the National Information Infrastructure (NII) initiative gives no priority higher than to what Vice President Gore has called its "strong mandate to ensure universal service in the future ..." 3 This commitment reflects economic and social concerns made urgent by injecting competition into an industry that no longer will be heavily sheltered by regulation and crosssubsidy, which could make service less accessible for many. Without special compensations to assure universal service, competitors in telecommunications would likely pass up serving less profitable customers. The Administration has pledged not to permit this to happen, emphasizing that "advanced services should be available to rural and urban lower income users, to users in areas where the costs of service are high, and to social institutions, especially educational and health-care facilities." 4

Implementing bills in both the House and Senate this year sought to address this concern. Yet neither chamber fashioned an actual solution to guarantee universal service, and both efforts were merely hortatory and tentative-no less than the existing Communications Act of 1934, which for 60 years has striven for universal service only "so far as possible." Neither bill could do more than continue regulatory engagement supervised overall by federal and state regulators acting in concert to coordinate contributions mandated from all telecommunications providers. Various specific expedients were referenced in the bills but they were not intended to eliminate other options.

The Senate bill specifically recognized the possibility that utilities could make special contributions under FCC regulations as "infrastructure providers" that would not provide telecommunications services to the ultimate consumer and would build common facilities that "telecommunications carriers" would share, pursuant to integrated "network planning" procedures to be adopted in each state.

One possibility that might result from utility participation is that competing local loops would be built more surely if a well-heeled third party-the electric utility-could readily join in, thereby fortifying the competitive model against its economic fragility (already manifest in the failure last spring of the Bell AtlanticTCI merger, among others). Another and more novel possibility (discussed in the closing Chapter 4 here) would be for the utility to build a common infrastructure to be shared by phone companies, cable companies, and others who would compete with each other (but not with the utility).

Significantly (as stated below), electric utilities serve one percentage point more of the U.S. residential population than the telephone companies-95\% compared to $94 \%$-and $30 \%$ more than cable television. Energy savings believed attainable could significantly reduce the average consumer's electricity bill more than $\$ 700 /$ house/year, creating a huge pool of investment capital much faster and with greater certainty perhaps than video-on-demand and entertainment television.

So a logical application exists for the windfall from the electric business-to speed the expansion of telecommunications services to difficult-to-serve

\footnotetext{
${ }^{3}$ Remarks by Vice President Gore at UCLA, January 11, 1994, p. 8.

${ }^{4}$ Administration White Paper on Communications Act Reforms, January 28, 1994, p. 5.
} 
customers and markets. One should also keep in mind that a further requisite exists for universal service in electric markets as well: How can a power company justify extending real-time electricity pricing to only 40 percent of its own customers (as Entergy would do) when it, no less than a telecommunications carrier, also has state-based requirements to provide universal, nondiscriminatory service?

Fortuitously, responsibility for determining how to dispose of the windfall in an IOU's electricity business rests with precisely the same entity responsible for assuring universal telecommunications service-the Public Utilities Commission (PUC). Ultimately, such regulators must appreciate their new option to serve ratepayers in both industries, if they can be flexible in their traditional rules of prudence--just as they have been from time to time in pursuing policy objectives such as demand-side management and the write-off of troubled generating plants, through such incentives as liberal allowance of ratebasing.

New federal telecommunications legislation can also simplify the task by enacting a mandate to achieve universal telecommunications service (like the 1994 bills). Next year electric utilities could be even more explicitly rewarded through assured rate-base treatment for telecommunications facilities and services purposely developed to foster universal coverage.

The unsolved challenge of ensuring universal service is one very potent reason regulators and the utilities they regulate will get together to slice up the windfall of excess capacity in utility telecommunications systems to benefit both the utilities and society as a whole.

In Chapters 2 and 3 we turn to how and why this new opportunity for electric utilities could now come into being. 


\section{Chapter 2}

\section{DO ELECTRIC UTILITIES HAVE LEGAL AUTHORITY TO BUILD THE NATIONAL INFORMATION INFRASTRUCTURE?}

A century of restraint has left many electric utilities uncertain of whether they can lawfully build telecommunications infrastructure or provide telecommunications services to the American public. 5

Though circumstances differ from one utility to another and from place to place, utilities nevertheless do have substantial authority to construct and deliver telecommunications, an authority contingent more or less explicitly on helping manage electric utility systems. ${ }^{6}$ These powers were fashioned before the modern significance of utility telecommunications was realized, at a time when utilities' functions were rather different from what they are now and soon will become.

The efficient operation of a utility today justifies real-time interaction with consumers buying electricity. It follows that the utility's legal rights to build and conduct telecommunications could be as elastic as its operational needs: If these telecommunications powers extend as far as the utility's new reach, the utility would be able to build the critical last mile of the National Information Infrastructure (NII). Though the prospect is not entirely free from controversy and will hinge on the utility's assertiveness and flexibility, the utility should be assured it is legally eligible to become a prime mover in the NII.

In this way, the ongoing evolution of the electric utility holds significant implications for power companies, for their regulators, for competitors in telecommunications, for customers, and for society and the economy as a whole.

This inquiry aims to illuminate the diverse potential of electric utilities to initiate broadband telecommunications to the residence, based on a review and analysis of their legal authorities to build telecommunications facilities and deliver telecommunications services. ${ }^{7}$ The analysis here is empirical and

\footnotetext{
${ }^{5}$ Thomas Edison made fundamental contributions to both industries at their launching over a century ago. Yet services to the public developed in complete separation, probably because electromagnetic radiation menaces electronic telecommunications. Nevertheless, the technological and economic histories of these two utilities in relation to each other appear completely unknown and would benefit from competent scholarly exploration, now that technology and economics promise some convergence in the near future.

${ }^{6}$ Many of them have taken advantage of these powers to build telecommunications plant, often leased to long-distance carriers: "According to a 1993 estimate prepared by the FCC's Industry Analysis Division, interexchange carriers have installed over 100,000 fiber miles ( 4,700 miles of cable) within electric utility rights-of-way (e.g. buried next to transmission towers) throughout the country." (Testimony of Michael L. Katz, FCC Chief Economist before Subcommittees on Telecommunications and Finance and Energy and Power, House Committee on Energy and Commerce, July 29, 1994, p. 4.)

${ }^{7}$ The utilities' freedom of action will also be shaped by federal and state regulation, aiming to protect consumers and, at times, investors or competition, in both the telecommunications and electricity industries. Questions on rates, competition, concentration of ownership, and diversification under these various regulatory regimes could impose serious practical restraints on electric utilities. This investigation deals with such possibilities only in passing, because the public interest now would much more likely favor than retard utility entry into telecommunications. For example, legislative initiatives to reform federal telecommunications
} 
comprehensive, but not exhaustive, as thousands of discrete situations make up the national mosaic, though most fall into common patterns. Case examples illustrating these patterns will be presented, drawn from public records that have come to the author's attention during more than 15 years of law practice in this area. 8

\subsection{Introduction}

The electric utility originated in the last quarter of the nineteenth century. Its existence was shaped, in the first instance, by its corporate charter-in the case of investor-owned utilities (IOUs), a contract of association among individual incorporators much like any other voluntary undertaking to launch a profitmaking; enterprise with limited liabilities. Delivery of electric services to customers also necessitated that the utility reach agreements with municipalities-the franchise - to license hazardous activities, sometimes also to stipulate terms of service (including rates), usually also to secure a compensating fee for the franchising authority based on the utility's gross receipts, and, frequently as well, to restrict competition. Reaching customers' premises required physical connections to the utility, implemented via rights-of-way negotiated with political authorities in and across public property and easements from landowners to use private property, acquired by contract or eminent domain. All of the foregoing, dating from as much as a century ago, define the utility's basic legal powers today.

As electric service increasingly came to be viewed a necessity, public discontent mounted over selective coverage offered by IOUs, spurring creation of alternative, publicly financed entities. By 1900, many cities and some counties had begun to initiate electric service themselves, creating the municipal utility as a unit of local government and, legally, of state government also. Generally, a state statute delegated specific authority to the municipality or to a special-purpose government district to provide for utility service, financed usually by taxfree bonds backed by the credit of the locality that it would repay the principal out of tax proceeds or future system revenues.

Later on, during the New Deal, the rural cooperative was created, a consumer-owned, not-for-profit membership corporation chartered pursuant to state statute and financed at the outset by low-interest federal loans from the Rural Electrification Administration (REA) of the U.S. Department of Agriculture.

Following years of often rancorous jockeying for territories, the pattern of utility service from these three types of entities to ultimate customers (112.8 million today, in all categories) has become mostly stable. Of the total ultimate customers, $76.4 \%$ are served by IOUs ( 86.2 million customers), $13.7 \%$ by municipals and other public agencies (15.4 million customers), and $9.9 \%$ by rural electric cooperatives (11.2 million customers). ${ }^{9}$ In all, about 95 percent of the American

laws (adopted in the House in June 1994 but not to be acted on in the Senate prior to adjournment in October) would preempt authority from the states to assure that "any entity" - by implication including electric, gas, water, or steam utilities-may provide telecommunications services.

${ }^{8}$ The author has on occasion provided advice to some of the power companies referenced here; in all such instances the information referred to will be freely and widely available to the public.

${ }^{9} 1992$ Pocketbook of Electric Utility Industry Statistics, Edison Electric Institute, p. 119. 
people receive electric service from utilities. ${ }^{10}$ At present, few customers have the option to shop among more than one distributor of electricity, though the possibility of "retail wheeling"11 promises to make more competitive choices available to the ultimate customer soon.

One additional distinct category completes the array of entities serving customers at retail ${ }^{12}$ - the multistate investor-owned holding company required to be registered with the U.S. Securities \& Exchange Commission (SEC) under the Public Utility Holding Company Act (PUHCA). ${ }^{13}$

Enacted as a centerpiece of the New Deal in 1935, PUHCA positioned the SEC to curb widespread abuses that were attributed to many IOU parent companies using their multistate form to dodge the regulatory jurisdiction of state public utilities commissions. To protect both investors and ratepayers, PUHCA requires that registered holding companies be confined to "such other businesses as are reasonably incidental, or economically necessary or appropriate to the operations of [an] integrated public-utility system ..."14 —as a practical matter limiting the utility's ability to expand its enterprise outside the utility business. ${ }^{15}$ A total of eleven registered electric holding companies now survive, ${ }^{16}$ serving about 20 percent of the IOU electric market, or just under 16 percent of all electric customers.

The three main categories of utility (IOU, municipal, and co-op) and the fourth embraced within the IOU (the registered holding company, or RHC) all function, in somewhat different ways, within tight legal boundaries, yet all four are endowed with legal authority vis-à-vis telecommunications that gives utilities leeway to build infrastructure and to deliver at least some utility-related telecommunications services.

The next four sections of this chapter provide particularized examples bearing out this assertion for each type of entity, and a final section states the author's reasons for believing that these authorities will enable electric utilities (if they wish) to bring the NII right to the American home.

\subsection{Legal Authorities of Investor-Owned Utilities}

From the very beginning of their involvement in the little-known and inherently dangerous technology of electricity, Edison's progeny acquired leeway to conduct their business in the most practical, and safe, way possible. For instance, in Boise, Idaho, Capital Electric Light, Motor \& Gas Company (the predecessor of Idaho Power) acquired broad powers initially "to erect poles and

\footnotetext{
${ }^{10}$ Statistical Abstract of the United States-1993, pp. 589 and 728.

${ }^{11}$ See Orders Instituting Rulemaking and Investigation of the Commission's Proposed Policy Governing Restructuring California's Electric Services Industry and Reforming Regulation, California Public Utilities Commission, R.94-04-031 and I.94-04-032, April $20,1994$.

${ }^{12}$ These categories have not been used to define the generation and transmission segments of the industry. Increasingly, the vertically integrated utility is giving way to competition, but not yet in distribution-the "natural monopoly" characteristics of which appear likely to retain their traditional validity for the foreseeable future.

${ }^{13} 15$ U.S.C. Sec. 79 , et seq.

14 Sec. 11(b)(1) of the Public Utility Holding Company Act, 15 U.S.C. Sec. 79k.

${ }^{15}$ The Act was intended to induce the holding companies to "rearrange or reduce their holdings in operating companies ... so that each holding company will control the management of only a single system of operating companies, which single system is not mixed up with any extraneous businesses such as real estate, hotels, and operations in foreign countries." (S. Rep. No. 621, 74th Cong., 1st Sess. 11 [1935].)

${ }^{16}$ Plus three more involved in natural gas.
} 
stretch wires along and across the streets and alleys of Boise City for electric light purposes." 17

Later, by 1903, the electric business had grown functionally beyond street lighting, to serve the premises of individual customers for many ultimate applications, and territorially beyond the limits of incorporated cities, ${ }^{18}$ necessitating that new rights-of-way be granted from the state of Idaho. These rights-of-way were couched in deliberately generous terms, granting to entities

supplying, transmitting, delivering, or furnishing electric power or electric energy by wires, cables, or any other method, or means ... the right to erect, construct, maintain, and operate all necessary lines ... together with the right to erect, construct, maintain and operate upon said electric power line a telephone line to be used only in connection with the said electric energy and power line ...19

When public utility regulation thereafter came to Idaho, a statutory formula was adopted for ratemaking that likewise gave a deliberately broad connotation to the utility's "electric plant," to include

all real estate, fixtures and personal property owned, controlled, operated or managed in connection with or to facilitate the production, generation, transmission, delivery or furnishing of electricity for light, heat or power ...20

Leaving no doubt that it viewed its own powers expansively, Idaho Power adopted forms of power-line easements to deal with individual landowners that specifically enabled the utility to place multiple "telephone lines and circuits of the Grantee $^{\prime 21}$ over and across affected lands.

Similar explicit terminology has been in common use in forms of easement throughout the country. Some parts of Mississippi Power Company's distribution sysitem, for example, extend through easements that include the "right to construct, operate and maintain electric lines and all telegraph and telephone lines ... and equipment ... necessary or convenient in connection therewith" (emphasis added), while other forms of easement more simply convey rights to string "electric power and telephone wires ..." (emphasis added). ${ }^{22}$ However, instances are found where no express mention of telecommunications was made, perhaps because of faulty drafting. ${ }^{23}$

${ }^{17}$ Boise City Ordinance No. 101, September 4, 1890 (emphasis added).

${ }^{18}$ Comparably, in New Orleans in 1892, the Algiers Ice Manufacturing Company was authorized by the New Orleans City Council to place "all such wires, conductors, mains and cables as shall or may become necessary to establish ... electric lights." Ordinance No. 6332 (emphasis added). In 1922, a successor, New Orleans Public Service, was awarded still more general rights "to construct or otherwise acquire, own, maintain and operate plants, works and systems ... for the generation and distribution of electrical energy for heat, light, power and other purposes ..." Ordinance No. 7068 (emphasis added).

${ }^{19} \mathrm{Sec} .62-705$, Idaho Code, formerly Sec. 2378, Idaho Revised Codes (emphasis added).

${ }^{20}$ Sec. 61-18, Idaho Code (emphasis added).

${ }^{21}$ Idaho Power Company forms of Power Line Easements below $69 \mathrm{kV}$ and above $69 \mathrm{kV}$. Similarly, Pacific Power \& Light's form of right-of-way easement enables PP\&L to place "an electric transmission and distribution line of one or more wires and all necessary or desirable appurtenances (including telephone and telegraph wires) ..." (emphasis added).

22 Mississippi Power Company forms of easement for $115 \mathrm{kV}, 230 \mathrm{kV}$, and $46 \mathrm{kV}$ and below.

${ }^{23}$ Nevertheless, failure to include sfecific telecommunications powers in an easement has been judicially ignored, allowing cable television distribution lines to be installed in an electric utility's easements as "no additional burden." Mumaugh v. Diamond Lake Area Cable TV Company, 456 N.W.2d 425 (Mich. App. 1990). "The broad scope of this easement could reasonably be construed as a dedication for any use by public utilities" (ibid. at 430), and Centel Cable TV Co. of Ohio, Inc. v. Cook, 567 N.E.2d 1010 (Ohio 1991). Inclusion of fiber-optic transmission linis was specifically allowed in Crommelin v. Alabama Power Company, 597 So.2d 683 (Ala., 1992). 
From this admittedly impressionistic summary of IOUs' statutory powers and rights of access, somewhat uneven patterns can be discerned, conveying both strengths and weaknesses as to powers to build telecommunications infrastructure and provide telecommunications services.

First, tracking the evolutionary beginnings of the industry, and especially its early growth by acquisitions of independent local companies, authorities are often inconsistent within the territory served by a single utility. As a result, building some portions of a utility-wide telecommunications system may be more readily permissible than others.

Second, most utilities appear to have some express authority to deploy a "telephone" line or lines, or, broader still, "communications." Sometimes, but not always, the authority is conditioned upon the use of the line for "utility" purposes. Sometimes, authority for telecommunications is not explicit but only inferable from general powers to build electric plant "and all necessary appurtenances."

But simple problems of interpretation abound; for example, whether the singular also connotes the plural (can "lines" be read for "line"?) and whether "telephone" means just voice and negates some other analog wave form such as video. Do such technologically quaint and dated classifications as "telephone" or "communications" retain any limiting meaning when the medium of choice becomes broadband - coax and/or fiber-and transmits digits not waves, and all the digits (whether the utility's or someone else's) are mutually intermingled and indistinguishable?

Third, case law is not much help, since the boundaries of utilities' telecommunications powers appear not to have been tested in any directly relevant way and assuredly not in the context of building broadband, multipurpose systems. Governing principles of construction are ambiguous, at best. Thus, on the one hand, according to the leading treatise, franchises

being considered in derogation of the right of the public to free and unobstructed use of the streets, are strictly construed, and if the terms of the franchise are doubtful and susceptible of two or more constructions, they are construed strictly against the grantee and in favor of the public.

But, on the other hand,

a just and reasonable construction is required. A grant to use the streets is not to be frittered away by construction. It is to be held up by the four corners and examined and given a fair construction, i.e. a reasonable construction consistent with common sense. A construction that would lead to false consequences or inconvenient results, not contemplated or intended, should be avoided. ${ }^{24}$

The commentator proceeds to list a "miscellany of decisions" that go both ways. ${ }^{25}$ Thus, a franchise for natural gas could substitute artificial gas, but a franchise to transport oil and gas could not carry water. A telephone company with rights to string "a telephone line". in a street could install an exchange in the street, and a "street railway system" could run sightseeing busses. Tantalizingly,

${ }^{24} 12$ McQuillen, Municipal Corporations, Sec. 35.45, pp. 146-147.

${ }^{25}$ Ibid., Sec. 34.54a, p. 151. 
because it would be most closely relevant, a "telephone company" could carry radio, television, and teletype services in addition to voice. ${ }^{26}$

Fourth, no IOU would want to guess wrong, since a municipality, competitors, or ratepayers might pounce upon conduct labeled "ultra vires" beyond the lawful powers of the utility-and try to get that conduct judicially enjoined. The question of whether a utility is acting in accordance with its lawful powers has a particularly sharp bite against directors and officers who have guessed wrong: They can be sued as individuals for money damages by shareholders on behalf of the company for having done their jobs without "due care", 27 ' however, in such derivative shareholder suits, proof of having relied on explicit expert advice is a usually a workable defense (the "business judgment" rule). Moreover, most corporations pay for directors' and officers' insurance to indemnify key personnel against liabilities for such claimed mistakes.

Fifth, utilities have a deep pocket to pay for litigation affecting their rights to do business (the costs of which can be passed on to customers). As a practical matter, the utility's litigating resources are likely to intimidate the other side, even a public body. Such disparities of strength can be the a margin of ultimate victory in a real fight, especially if the utility's conduct is economically justified and holds broad public appeal.

Next, who benefits from the excess capacity on a broadband system built by a utility is likely to be controversial. Critics of Entergy's investment in a potential multipurpose customer-controlled load-management system in Arkansas and elsewhere frequently point out that the load-management applications will use no more than two percent of the capacity (i.e., bandwidth) of the system. ${ }^{28}$ Assuming the expenditure of such magnitude on a telecommunications facility is cost-justified for load-management uses, building a system with inevitable excess capacity is not ultra vires for the IOU. Allocating costs and accounting for revenues attributable to the excess capacity, however, could be construed as regulatory issues - not questions of fundamental powers-which necessitate horse-trading with regulators to harmonize public and private interests. ${ }^{29}$

Finally, as stated earlier, it is improbable that an IOU's expansion into telecommunications will be entirely free from controversy. "Here died John Jay, defending his right-of-way" is an old aphorism no less apt for the power companies too, though they are hardly likely to suffer such a dire fate, even when butting heads with telephone companies or challenging big city governments. Electric utilities may not hold all the cards, but they nevertheless have a very good hand. So in many instances they would be well advised to negotiate for an assured, or even favored, outcome that reflects their unquestionable abilities to contribute significantly to the NII.

Such is the course already being taken by the registered holding company Entergy in New Orleans to dampen the most contentious challenge so far to any

\footnotetext{
${ }^{26}$ Waterville v. Bartell Tel. TV Systems, 233 A2d 711 (Maine, 1967) and Southern Bell Tel. \& Tel. v. Meridian, 131 So.2d 666 (Miss., 1961).

${ }^{27}$ For instance, some shareholders helve brought "derivative shareholder suits" against utilities' officers and directors for claimed frauds involving failed nuclear power plants, such as Stepak v. Addison, 11th Cir., Nos. 91-8945 and 92-8379, and 26 BNA Securities Regulation \& Law Rpt., 666, May 4, 1994.

${ }^{28}$ See Statement of Herschel L. Abbott, Jr., General Counsel, Louisiana, BellSouth Communications, before the Subcommittees on Energy and Power and on Telecommunications and Finance of the House Committee on Energy and Commerce, July 29, 1994, p. 2.

${ }^{29}$ In Chapter 3, the author suggests that the ultimate regulatory quid pro quo for the utility to build multipurpose broadband systems financed by energy savings will be its ability to contribute uniquely to accelerating universal service.
} 
utility's telecommunications plans, a challenge brought by the City of New Orleans and encouraged by the incumbent telephone and cable companies. ${ }^{30}$

Entergy's local subsidiaries, New Orleans Public Service, Inc., (NOPSI) and Louisiana Power \& Light (LP\&L), have proposed a compromise to avoid a confrontation until after they have proved a compelling case to build a broadband network to carry out load management. On June 5, 1994, NOPSI and LP\&L applied for a "limited franchise" that would enable them to show the benefits of energy-saving via telecommunications over a fiber/coax broadband system; their test will reach 1,600 points and will last for two years.

The power company is not attempting to build permanent telecommunications facilities under its existing franchise but is, for the time being, willing to avoid a test of those powers. Presumably, if the 24-month demonstration concludes successfully, the power company and the city will thereafter open up negotiations over new long-term arrangements based on mutual interest and founded on verifiable facts. Existing legal authorities will have helped the utility bargain for a solid base in telecommunications for the future-as would also be the case were power companies elsewhere to attempt to negotiate an updated long-term position.

\subsection{Legal Authorities of Registered Holding Companies}

Investor-owned utilities that by virtue of their multistate structure are registered holding companies (RHCs) (as is Entergy) must carry an additional regulatory burden even if their legal powers are adequate, or can be made adequate, to support telecommunications infrastructure investment. RHCs must secure specific approval from the SEC before they can make any investment in any business, including the purchase of "utility assets." 31

But, when an RHC is prepared to justify a telecommunications investment as a "utility asset," the utility may make the investment if the SEC finds that the RHC has satisfied a twofold test: The acquisition must bear a "functional relationship" to the utility, meaning that the acquisition is "reasonably incidental, or economically necessary or appropriate to the operations of [an] integrated public utility system," and, moreover, that the acquisition is "necessary or appropriate in the public interest." 32

RHCs have frequently been disappointed by the SEC's decisions to halt activities initiated within the utility enterprise that potentially have a far greater commercial market. For example, in 1982 Mississippi Power \& Light Company

\footnotetext{
${ }^{30}$ The controversy is described by the city's attorneys in an article designed to stimulate municipalities' awareness of utilities' readiness to move into telecommunications throughout the country. See Vince, Fogel, and Nordstrom, "Fiber Optics, Electric Utilities and the Information Superhighway-The Community's Role," The Electricity Journal, February 1994, p. 34.

${ }^{31}$ Sec. 9(a)(l) of the Public Utility Holding Company Act, 15 U.S.C. Sec. 79i(a)(1).

${ }^{32} \mathrm{Sec} .11(\mathrm{~b})(1)$ of the Public Utility Holding Company Act, 15 U.S.C. Sec. 79k. The twofold test for a "functional relationship" was stated by the SEC in Michigan Consolidated Gas Company et al., 44 SEC 361 (1970), aff'd, sub nom., Michigan Consolidated Gas Co. 0. SEC, 444 F.2d 913 (D.C. Cir. 1971). Meeting the SEC's test is often an elusive exercise:

Examples of the kinds of nonutility businesses approved by the SEC as functionally related are merchandising of appliances, pipeline construction, railcar repair facilities, production and transmission facilities, coal properties, railroad spurs, oil and gas exploration, lending for the purpose of installing insulation, gas byproducts, refineries, and uranium.

Businesses that the SEC has found not to be functionally related include housing construction, land development, electrical instruments, pulpwood, cable television, and, for gas utilities, cogeneration." (Hawes, Holding Companies, Sec 3.05[1], p. 3-30.)
} 
desired to build a cable television system in Jackson, Mississippi. ${ }^{33}$ In its application to the SEC, MP\&L noted that "a two-way, interactive coaxial cable system ... has potential feasibility in utility applications that would include load management and other utility services through channels capable of receiving and transmitting data." Nevertheless, the Commission expressed doubt that the telecommunication load-management technology was ready for deployment and doubt that MP\&L's actual "intentions and motives" gave assurance of the "functional relationship" that the Act requires. The Commission denied the requested approval, concluding:

The dominant activity of the new company would be the operation of a. cable television system. Bands on the cable available for two-way communications would constitute a relatively small percentage of the total bands on the system. The two-way data communication for MP\&L's utility operations, should it prove feasible, does not render the cable television operations, constituting the primary and dominant business of the new company, functionally related to MP\&L's electric utility business. ${ }^{34}$

Since the MP\&L turndown, the SEC has had several occasions to review applications by RHCs to build mixed-use (long-distance) fiber-optic telecommunications systems. In these applications the utility clearly established it would use telecommunications for electric system control, and the Commission recognized that use as the "primary and dominant" purpose. In its Appalachian Power Company decision in 1988, the Commission developed a "50 percent" rule, whereby acceptance of utility uses as the primary purpose was established because the RHC committed itself to lease out no more than half the capacity of the system - on a merely temporary basis-and to use the proceeds to reduce the cost to the electric ratepayer. ${ }^{35}$ More recently, the Commission approved similar plans of Central and South West Corporation, which would lease out as much as 20 of 4.2 fibers in a planned system, not requiring this time any stipulation that the use by nonaffiliates would be only temporary. ${ }^{36}$

The Commission has confirmed its determination to hew to its 50 percent rule in CSW Credit, Inc., another recent decision involving Central and South West, in which the RHC's request was denied that its subsidiary that factors accounts receivable be allowed to do more than 50 percent of its business for other utilities. ${ }^{37}$ The decision distinguished a 1987 case, Jersey Central Power \& Light $\mathrm{C}_{0 .}{ }^{38}$ which relaxed the 50 percent rule because three circumstances were present that were not established in CSW Credit, Inc.:

(1) the non-functionally related business evolved in connection with the system's utility business; (2) the investment in the other business was not significant in relation to the system's total financial resources; and (3) the investment had the potential to produce benefits for investors or consumers.

\footnotetext{
${ }^{33}$ MP\&L's RHC parent, Middle South Utilities, is now called Entergy.

${ }^{34}$ Mississippi Power \& Light Company, 1982, Fed. Sec. Rep. (CCH), Sec. 77,241.

35 Appalachian Power Company, SEC Holding Company Release No. 35-24772, December 9, 1988.

${ }^{36}$ Central and South West Corporation, SEC No. 70-8199, June 3, 1994.

${ }^{37}$ CSW Credit, Inc., SEC Admin. Proc. File No. 3-7027, March 2, 1994.

${ }^{38}$ Jersey Central Power \& Light Company, Holding Company Act Release No. 24348, 37 SEC Dkt. 1660, 1664, March 18, 1987.
} 
Factually, the Jersey Central case involved licensing to nonaffiliated utilities a computer program developed in-house designed to track theft of services and identify offenders. ${ }^{39}$

In 1994, the RHCs lobbied intensively to secure a legislative exemption for their investments in "communications entities" 40 comparable to limited exemptions they recently won for investments in "exempt wholesale generators" and in foreign utility companies in the Energy Policy Act of 1992.41 The holding companies have alleged that continuing PUHCA restrictions would deny themalone of all utilities-the opportunity to enter the communications business, even as NII legislation would preempt state telecommunications regulation to open the "local loop" to all comers. ${ }^{42}$

Opposition to the RHCs' expansion and the stalling of telecommunications reform this year have blunted the drive to reform PUHCA to permit unregulated entry into telecommunications. On July 18, 1994, the SEC held a public roundtable discussion on PUHCA's future, marking 60 years since PUHCA's passage, and announced the Commission was undertaking a comprehensive study of its authority under the Act, devoting specific attention to how entry into telecommunications would fit in context with the other recent changes to the Act.

Planned to take up to a year to complete, the SEC's comprehensive internal review is likely to slow any earlier action in Congress. Moreover, in a hearing held before two House Energy and Commerce Subcommittees jointly on July 29, a need was identified, in the event of a PUHCA repeal affecting telecommunications, to work out a regulatory realignment involving not only the SEC, but also the Federal Energy Regulatory Commission (FERC), the Federal Communications Commission (FCC), and state regulatory commissions. The chair of the House Telecommunications and Finance Subcommittee, Rep. Edward Markey, also expressed strong views that completely unregulated entry by RHCs into telecommunications would introduce serious inequities vis-à-vis other regulated telecommunications entities (telephone and cable companies), a problem of substantive proportions that he indicated must be resolved before his subcommittee would acquiesce in any PUHCA relief for telecommunications.

So what are the prospects for PUHCA relief next year in the holding companies' quest to enter telecommunications without restrictions, assuming they will renew their drive for repeal?

In the first place, it is fair to predict that the SEC's considered proposals, when available, will receive some deference from Congress. Moreover, the regulatory bugs and telecommunications policy questions identified by the House

\footnotetext{
${ }^{39}$ “In such cases, the approved businesses involved the sale or lease of products or skills of some complexity developed by the holding company at considerable expense for the benefit of its utility subsidiaries and not readily available to the rest of the public from other sources. Moreover, these endeavors generally required little or no further investment by the holding company, and permitting the proposed activities would permit amortization of product development expenses with little or no risk." (CSW Credit, Inc., citing Jersey Central.)

${ }^{40}$ In the House, an outline for a measure of "PUHCA relief" was called the Boucher Bill (after its initiator, Congressman Rick Boucher), though it was never actually filed as a bill. A comparable provision was added by the Senate Commerce Committee, and approved as Sec. 230 (b) of S. 1822, but the bill stalled on September 23, before Senate action.

${ }^{41}$ See 15 U.S.C., Secs. 79z-5a and 79z-5b. Earlier, another statutory exemption was secured under Section 210 of the Public Utilities Regulatory Policy Act of 1978 (PURPA), 16 U.S.C., Sec. 824a-3, allowing RHC acquisition of "any qualifying cogeneration facilities and qualifying small power production facilities ..." See 15 U.S.C., Sec. 79k NOTE.

${ }^{42}$ The final version of S. 1822 was explicit in preempting from states and localities to halt them from "prohibiting the ability of any entity to provide any interstate or intrastate telecommunications services." Sec. 230 (a). House-passed provisions were similar. An earlier version of S. 1822 reflected Administration emphasis on specifically inviting all utilities to participate in local telecommunications.
} 
Energy and Commerce Subcommittees will also engender more legislative scrutiny in 1995 than they received in 1994.

Second, failure of telecommunications reform to pass has given the holding companies a new opportunity to seek out and find a congenial niche in the grand design for telecommunications policy being forged on Capitol Hill. ${ }^{43}$ As long as the holding companies counted on winning a complete exemption from federal regulation, they apparently did not consider they might need a fallback position if they had to make do with less freedom of action: They wanted only to have all their options open. Such a fallback position may now be prudent to consider.

Third, the existing functional relationship test under PUHCA offers a flexible, if inherently conservative, standard for eventual expansion by holding companies into telecommunications that is likely to retain the favor of the SEC, as its maintenance would continue to provide for some continuing regulatory review. If, for example, Congress were to legislate specific standards for telecommunications investments that would introduce new flexibility into that traditional functional relationship test, the regulatory task would be greatly simplified. ${ }^{44}$

As noted above, the SEC has expressed its willingness to stretch the functional relationship standard where its three-part test in the Jersey Central case was satisfied. Also, in a memo submitted to the House Committee earlier this year commenting on the Boucher Bill, the SEC staff proposed that Congress legislate specifically to recognize that telecommunications investments would amount to a functional relationship for the holding company in instances where the FCC had specifically signed off and the investment would constitute no more than 10 percent of the retained earnings of the utility system, thereby achieving both consistency with federal telecommunications policies and also minimizing risk to utility ratepayers. 45

Finally, and more broadly, this functional relationship test resonates strongly with the nature of the economic opportunity before the RHCs in particular and electric utilities in general as they enter local telecommunications. Surely, controlling electricity demand and supply via telecommunications bears a functional relationship to running a utility. Very likely, the value of electric efficiency made possible by telecommunications will exceed the cost of the telecommunications facilities needed to serve a large portion of the utility's customers, so such telecommunications facilities will eventually be fundable out of system revenues.

From the perspective of the utility, the opportunities are understandably tempting to make as much money for shareholders as possible from the facilities' excess capacity. From the perspective of society as a whole, how much profit should the utility be enabled to take from this windfall from its regulated electric business, and when? How free a hand should the holding companies have in entering telecommunications markets in which its competitors (telephone and cable companies) will still have regulatory constraints and responsibilities to the public? To focus the key question as a political (rather than a legal) issue: Should there be any regulatory quid pro quo for allowing a power company to enter telecommunications?

\footnotetext{
${ }^{43}$ See "No Day in Court for Baby Bells," New York Times, July 6, 1994, p. A18 (editorial).

${ }^{44}$ Comparably, perhaps, in the Gas. Related Resources Act of 1990, P.L. 101-572, Congress authorized the SEC to interpret as satisfied the functional relationship test for RHC acquisitions of any natural gas or gas transportation company and for other companies organized to provide for the supply of natural gas. See 15 U.S.C. Sec. $79 \mathrm{k}$ NOTE.

${ }^{45}$ Memorandum from the SEC Office of Legal and Policy Analysis, dated February 9, 1994, transmitted to Chairman Markey by Arthur Levitt, Chairman of the SEC, on February 17, 1994.
} 
These are legitimate legislative and regulatory concerns, which can now be addressed forthrightly in the months ahead, and the holding companies will have an opportunity now to prepare their specific and responsive proposals. ${ }^{46}$ At a time when PUHCA's central notion of an "integrated public utility systam" may be coming apart at the seams for economic reasons, ${ }^{47}$ a comprehensive and thoughtful reevaluation of regulatory responsibilities could well recognize the beneficial consequences of realigning and integrating electric and telecommunications distribution services.

\subsection{Legal Powers of Municipal Utilities}

The powers of municipal utilities are defined by both state enabling legislation and local ordinance. If a state and city have legislated explicitly, all doubt is removed as to whether municipal utilities have powers to enter telecommunications.

One instance of where a state has so acted (regarding municipalities' powers to construct and operate a cable television system) is in Arkansas, where the legislature provided in 1987 as follows:

Any first-class city, second-class city, and incorporated town may own, construct, acquire, purchase, maintain, and operate a television signal distribution system for the purpose of receiving, transmitting, and distributing television impulses and television energy, including audio signals and transient visual images, to the inhabitants of the city or town and to the inhabitants of an area not to exceed two (2) miles outside the boundaries of the city or town." (Ark. Code Ann. Sec. 14199-601[a].)

Accordingly, in Paragould Cablevision v. City of Paragould, 930 F.2d 1310 (8th Cir., 1991), the Arkansas Supreme Court held that the City of Paragould could authorize its municipal utility to construct such a system.

While no instance has been found of a state having yet legislated specifically to authorize municipal utilities to construct a multipurpose broadband telecommunications system, the Washington legislature this year considered an omnibus telecommunications reform bill that would have included such authority for Public Utility Districts (PUDs), ${ }^{48}$ but the bill did not pass. But even without such specific legislative action, many municipal utilities may be able to resort to implications drawn from their general powers to construct and manage water and electric systems as authority to build telecommunications

\footnotetext{
${ }^{46}$ In Chapter 3, the prospect is considered that a rapid build-out of utilities' broadband telecommunications facilities would now be a timely expedient to meet the nation's unsolved needs for universal telecommunications coverage; such a build-out would also enable the utility to better serve all its electric customers. These hitherto unappreciated considerations may be the key reasons for now extending liberal public incentives to electric utilities (including the holding companies), allowing them to play a critical role as builders of the NII.

${ }^{47}$ See, for example, Agis Salpukas, "Electric Utilities Brace for an End to Monopolies," New York Times, August 8, 1994, p. 1.

${ }^{48}$ Section 43 of Senate Bill 6425 would have added a new section to Chapter $54.16 \mathrm{RCW}$, which would expressly authorize PUDs to construct and operate "high-capacity telecommunications equipment and plant for district use, including customer end-use metering or demand-side management or modifications to energy consumption." Since 1931, Chapter 54 has authorized PUDs to "supply public utility service, including water and electricity for all uses." These powers were enlarged specifically in 1975 to authorize operation of sewer systems as well. (RCW 54.16.1230.)
} 
essential thereto-comparable, as we have seen, to similar general powers that can be implied for IOUs. ${ }^{49}$

In Washington (as elsewhere), ${ }^{50}$ such an implication by necessity is warranted, if construction of a broadband network is sufficiently related to express objectives granted by the legislature. ${ }^{51}$ Since a utility's operations are deemed proprietary, courts will not strictly examine the underlying statute for requisite authority, 52 but will allow the utility discretion to determine what is necessary to accomplish its authorized goal; that discretion, though, may not be abused for a project "unreasonably large and entirely inappropriate for the accomplishment of the primary purpose of the ... District."

For municipalities in the State of Washington, however, there is a cautionary precedent fresh in their minds: the collapse of the Washington Public Power Supply System (WPPSS), which left many system bonds unenforceable against municipalities and public utility districts, because key instruments were not statutorily authorized or ratified by the legislature. ${ }^{54}$

In summary, the following observations about the powers of municipal utilities to build telecommunications seem warranted:

First, passage by a state legislature of specific statutory authorization to build and operate multiple-use broadband telecommunications systems would put a municipal utility on unassailable ground.

Second, municipal utilities' existing authorities to construct and maintain electric systems powerfully imply their rights to build and conduct telecommunications essential to manage the utility, pursuant to the Dillon Rule cited in note 50 above. More than likely, these rights would embrace the ability to at least construct significant portions of infrastructure.

Finally, while use of excess capacity for nonelectric purposes may be controversial unless specifically authorized by the legislature (just as in the case of a similarly situated IOU relying only on its inherent powers to run a utility), mere custodial management by the electric utility of the excess capacity would, as a practical matter, undercut opposition and insulate the enterprise as a whole. In other words, it would be acceptable to build the plant and use it for energy managgement, but the municipal utility would be protected from challenge if the

\footnotetext{
${ }^{49}$ Washington PUDs have, among other powers in RCW Chapter 54.16.040, "full and exclusive authority to sell and regulate and control the use, distribution, rates, service, charges and price [of electricity] ... together with the right to purchase, handle, sell, or lease ... all ... kinds of equipment or accessories necessary or convenient for the use, distribution, and sale [of electricity]."

${ }^{50}$ According to Sands \& Libonati, 2: Local Government Law, SeC. 13.04, "The sources of authority for local powers are exhaustively stated in Judge Dillon's well-known formulation encapsulating the case law of every jurisdiction:

It is a general and undisputed proposition of law that a municipal corporation possesses and can exercise the following powers and no others: First, those granted in express words; second, those necessary or fairly implied in or incident to the powers expressly granted; third, those essential to the accomplishment of the declared objects and purposes of the corporation,-not simply convenient but indispensable (citing Dillon, Municipal Corporations, 443-449, 5th Edition)."

Understanding what is "implied," "incident to," and/or "essential" is the stuff of which huge arguments are made in and out of courts.

${ }^{51}$ City of Tacoma 0 . Taxpayers of the City of Tacoma, 743 P.2d 793, 802 (Wash., 1987) (conservation program found to be sufficiently related to the operation of electric utility).

${ }^{52}$ Scott Paper Company v. City of Anizcortes, 578 P.2d 1292 (Wash., 1978).

${ }^{53}$ State ex rel. Public Utility District .No. 1 of Skagit County v. Wylie, 182 P.2d 706, 727 (Wash., 1947) (purchase of generating capacity 10 times larger than needed).

${ }^{54}$ Chemical Bank v. Washington Public Power Supply System, 691 P.2d 524 (Wash. Sup. Ct., 1984).
} 
management of its other-than-energy operations were turned over to someone else- on fair and remunerative terms, of course.

One way to assure that an intended telecommunications initiative was legitimate would be to fashion a compelling case in a specific instance. The object would be to seek relief from a court in the form of a declaratory judgment construing the public utility's implied powers, thus clarifying and confirming the municipality's authority in advance.

\subsection{Legal Powers of Rural Electric Cooperatives}

As a private entity, albeit one with significant public financial backing, the rural cooperative does not differ organizationally from the IOU, except in one significant respect-the nonprofit requirement of its charter. Such charters are issued pursuant to state enabling legislation more or less conforming to models first worked out by the Rural Electrification Administration (REA) in the 1940s. Again, the utility's purposes ${ }^{55}$ and powers ${ }^{56}$ are expansive. REA has also taken the lead to prepare model forms of easement that are in common use and that convey wide powers over telecommunications. ${ }^{57}$

The charter requirement for nonprofit operation takes much of the incentive out of the prospect that co-ops would provide telecommunications beyond the mere construction of infrastructure and energy load management. However, as with their successful ventures in distributing satellite dishes to members through the National Rural Telecommunications Cooperative, rural co-ops have the option of creating wholly separate affiliates to conduct such enterprises at an arm's length from the electric co-op. ${ }^{58}$

Light population densities in rural areas originally justified the creation of special programs and mechanisms to achieve universal electric service. Similar considerations may justify efforts adopting the same or similar mechanisms regarding rural telecommunications in the near future.

\subsection{Conclusions}

For all organizational types of U.S. electric utilities, there are substantial authorities to develop and deploy telecommunications facilities and to provide

${ }^{55}$ In Pennsylvania, the purposes are:

(1) The furnishing of electric energy to persons in rural areas who are not receiving central station service.

(2) Assisting in the wiring of the premises ... or the acquisition, supply, or installation of electrical ... equipment ... (15 Pa. Code Sec. 12403 [emphasis added].)

${ }^{56}$ Pennsylvania powers include:

(3) To generate, manufacture, purchase, acquire and accumulate electric energy, and to transmit, distribute, sell, furnish and dispose of such electric energy to its members only, and to construct, erect, purchase, lease as lessee, and, in any manner, acquire, own, hold, maintain, operate, sell, dispose of, lease as lessor, exchange and mortgage plants, buildings, works, machinery, supplies, equipment, apparatus and transmission, and distribution lines or systems necessary, convenient, or useful. (15 Pa. Code Sec. 12404 [emphasis added].)

${ }^{57}$ REA's model form of easement conveys rights to place "supporting telephone or telegraph wires of the Corporation or any Lessee thereof ..."

${ }^{58}$ More recently, co-ops are being viewed as useful agents for publicly sponsored programs to improve rural housing, to develop water and waste water facilities, and to effectuate health care. It is altogether possible that rural co-ops (electric as well as telephone) will also receive special consideration to assure that, through them, the NII can attain universal service. 
telecommunications services. These authorities are based on new interactive telecommunications and their growing importance to electricity distribution and, predictably, supply.

For a utility to build telecommunications facilities to reach all its customers and potential suppliers of electricity, consequently, appears legally sound, if contentious. Similarly, developing information services to effectuate energy management would also be within utilities' powers, regardless of corporate form.

Both endeavors, however, entail difficult economic and political problems that relate to the use of and benefit from the excess capacities unavoidably created thereby. Competitors and regulators are sure to challenge utilities' rights to exploit these excess capacities, but the utilities possess strong bargaining positions for at least three reasons:

First, since utilities have clear rights to bring such facilities and enterprises into being, they have considerable leverage with regulators and competitors alike to achieve newer arrangements that acknowledge the utilities' rights and interests and build upon them.

Second, since utilities have undeniable rights to read their own electric meters through telecommunications pursuant to their existing authorities, they may also have First Amendment protections under the U.S. and state constitutions (rights they share with their customers) to send any information they wish over their wires. ${ }^{59}$ As a practical matter, once the utilities commit themselves to building and turning on their facilities, the First Amendment may enlarge their powers significantly to enable them to resist much restrictive regulation.

Finally, the nation's need to finance construction of the NII and make it universal gives electric utilities a compelling reason to gain regulatory favor for the use of and profit from their excess telecommunications capabilities. This is a subject to which Chapter 3 turns, dealing with the special role electric utilities could play in assuring universal service.

\footnotetext{
${ }^{59}$ Similar arguments are winning cases for Bell operating telephone companies against restrictive federal and local regulation. See, for example, CEP Telephone Co. v. FCC, 830 F. Supp. 909 (N.D. Va. 1993), affirmed by the 4th Cir. (reported in Wall Street Journal, November 22, 1994, p. B4); U S West, Inc. v. FCC, _ F. Supp. __ (D. Colo. 1994) (reported in Wall Street Journal, June 16, 1994, p. B9); and BellSouth v. FCC, _ F. Supp. __ (N.D. Ala., 1994) (reported in Daily Variety, September 27, 1994, p. 4). Also, cable television companies have been winning First Amendment challenges against municipalities; see Preferred Communications $v$. City of Los Angeles, 13 F.3d 1327 (9th Cir. 1994), cert. den'd., 129 L.Ed. 2d 859 (June 1994). According to Michael Schrage in the Washington Post (September 30, 1994, p. B3): "Presumably, a power utility that wants to send information down its networks would enjoy the same First Amendment rights as a Baby Bell."
} 


\section{Chapter 3}

\section{HOW ELECTRIC UTILITIES CAN CONTRIBUTE TO UNIVERSAL TELECOMMUNICATIONS SERVICE}

The National Information Infrastructure initiative gives no priority higher than to its "strong mandate to ensure universal service in the future ..."60 This commitment reflects economic and social concerns made urgent by the problem that injecting competition into an industry no longer heavily sheltered by regulation and cross-subsidy will make service less accessible for many: without special compensations to assure universal service, competitors would likely pass up serving less profitable customers. The Administration has pledged not to permit this to happen, emphasizing:

... advanced services should be available to rural and urban lower income users, to users in areas where the costs of service are high, and to social institutions, especially educational and health-care facilities. ${ }^{61}$

\subsection{Congress Strives to Assure Universal Service}

Yet, so far, that overriding concern has not ripened into a practical, farreaching legislative solution. Though the telecommunications reform bills before the 103rd Congress echoed the Administration's intense concern-a priority that large and vocal portions of the public have come to share-the prospects for achieving a workable consensus this year stalled when the Senate failed to take up S. 1822. It is fair to say that both the House and the Senate recognized the seriousness of the problem but failed to come up with a confident solution.

Thus, H.R. 3636, passed by the House in June, made explicit the purpose to "preserve and enhance universal telecommunications service at affordable rates" 62 - until now merely implied in language of intent within the Communications Act of 1934, muted and qualified, that aims to

make available, so far as possible, to all the people of the United States, a rapid, efficient, Nation-wide, and world-wide wire and radio communication service with adequate facilities at reasonable charges . . .63

S. 1822, as reported out of the Senate Commerce Committee on August 11, was even more explicit, and, if anything, more emphatic, in articulating a "national policy goal":

\footnotetext{
${ }^{60}$ Remarks by Vice President Gore at UCLA, January 11, 1994, p. 8.

${ }^{61}$ Administration White Paper on Communications Act Reforms, January 28, 1994, p. 5.

${ }^{62}$ Sec. 101(b)(1), H.R. 3636.

$63_{47}$ U.S.C. Sec. 151 (emphasis added).
} 
To make available so far as possible, to all the people of the United States, regardless of race, color, national origin, income, residence in a rural or urban area, or disability, high capacity two-way communications networks capable of enabling users to originate and receive affordable and accessible high quality voice, data, graphics, video, and other types of telecommunications services. ${ }^{64}$

Yet neither bill actually fashioned solutions that would guarantee universal service, ${ }^{65}$ and both were essentially hortatory-like the Communications Act itself. Eioth measures pushed solutions off to the future by entrusting the task of finding them to regulatory bodies and processes, with guidance at times left deliberately sketchy. ${ }^{66}$

Thus the House bill established a federal-state "Joint Board" between the FCC and state PUCs and directed it to "recommend ... actions to the various Commissions" to preserve universal service. The Joint Board would develop a plan to "maintain quality services at affordable prices," to define the content of universal service to include "advanced telecommunications service," to establish "specific and predictable mechanisms," and to require that "all providers ... make equitable and nondiscriminatory contribution ..."67

The Senate bill was somewhat more precise, seeking to assure "universal service protection and enhancement" (Sec. 102) by

- Articulating "universal service principles."

- Defining "universal service" ("an evolving package of services").

- Creating an obligation upon all "telecommunications providers" to "contribute to the preservation and enhancement of universal service."

- Establishing a "universal service fund" to administer "universal service contributions."

- Establishing an FCC-led joint federal-state regulatory process to achieve universal service.

Also, the Senate bill included additional provisions that would create "public rights-of-way" in telecommunications networks by mandatory "reserved capacity" pursuant to FCC regulations for use by "eligible entities" at preferential rates (Sec. 103) and also create rights of "public access" (also at preferential rates) for "public facilities" (Sec. 104).

Generally, the Senate bill would have authorized the FCC to take the lead in the many regulatory proceedings envisaged, by which the content of universal service, its timing, and its financing would be pursued, with some lesser powers remaining to be exercised by state PUCs. However, overall FCC control would be effectuated through preemption in the event of conflicts.

\footnotetext{
${ }^{64}$ Sec. 101, S. 1822 (September 14, 1994, print).

${ }^{65}$ At a time when public life is rent with another clash between financial realism and universal service-over health care-it should not surprise that reconciling these two values challenges democratic institutions.

${ }^{66}$ Post-mortems in the popular press as to why reform of telecommunications laws failed to pass Congress identify both disaffection by most local telephone companies and also complexity and reliance on regulation as reasons for opposing the bills as they neared final passage. A case in point, the bills' treatment of universal service matured from being merely sketchy at first to becoming explicit and detailed by the time the process imploded in late September. The writer believes that the increasing definition given to this topic over time had the unfortunate consequence that many interests - some antagonistic to each otherwere alienated from the notion of passing any legislation this year.

${ }^{67}$ Para. 6, H.R. 3636.
} 


\subsection{Congress Starts to Recognize a Role for Utilities}

The speech by Vice President Gore in Los Angeles on January 11 affirming the goal of universal service also singled out electric utilities within a "federal standard that permits entry into local telephone markets" and prompted Congress to recognize the unique potential contributions of utilities. ${ }^{68}$

Attention to those potential contributions-especially from electric utilities themselves-grew stronger once the collapse of the Bell Atlantic-TCI merger in April began to suggest that telephone and cable companies, the main candidates to build local telecommunications infrastructure, were having doubts whether a competitive two-wire policy could be financially viable. Some commentators suggested that these doubts reflected the Bells' realization that the Administration's insistence on both real competition in local telecommunications and universal service would cost them too much and earn them too little-a view conveyed urgently to Congress. ${ }^{69}$

To cure this anticipated gap, the Bells sought quicker access to revenue by providing long-distance service, ${ }^{70}$ a market the original Senate and House bills would have barred them from until after local telecommunications had become fully competitive. When S. 1822 was amended in committee to sweeten the bill for the Bells, influential consumer opposition was added to the list of interests estranged from passing a bill this year. ${ }^{71}$

Another provision was added in committee; Sec. 229(c) recognized that utilities could make especially significant contributions to universal service in "rural markets and noncompetitive markets." By serving a function identified as "infrastructure providers" with rights to participate in a process regulated by the FCC known as "network planning," power companies would have been positioned to become a "dark horse" to build much of the NII. Infrastructure provider was defined as

any entity, such as a railroad, electric, gas, water or other utility, that builds and maintains an infrastructure and makes it available by lease or other arrangement to one or more telecommunications carriers, but which is not itself a telecommunications carrier.

With respect to "network planning," the FCC would be required to develop regulations that would preempt from states and localities to

\footnotetext{
${ }^{68}$ See note 60 above. The Vice President originally stipulated that "cable companies, long distance companies, and electric utilities must be free to offer two-way communications and local telephone service." (Emphasis added.) Language singling out power companies for specific federal preemption was included in the original S. 1822, but the bill that was brought to the Senate floor was less direct, specifically recognizing electric utilities in its findings as "prepared to enter the local telephone market over the next few years" (Sec. 2) and preempting state and local entry barriers that would prohibit "any entity" from providing telecommunications services. (Sec. 302.)

${ }^{69}$ See, for example, Peter Pitsch, "Disconnect the Universal Subsidy," in the Wall Street Journal, April 4, 1994, p. A12. This op-ed piece, written by a consultant to telephone companies, urged that "policy makers should take care not to undermine [voluntary development of the information superhighway] with premature talk about universality and subsidized access. This will only distort investment."

${ }^{70}$ Local telephone service has always been subsidized by revenues from long distance: before the AT\&T breakup the subsidy was accomplished by internal accounting; subsequently, the subsidy comes from access charges, which raise the price of a longdistance call by as much as 50 percent. An additional subsidy source driving down the cost of residential service (and hence contributing to universal service by lowering average telephone bills) has been higher charges on business phones.

${ }^{71}$ Senator Howard Metzenbaum, for one, threatened to oppose passage of the bill because, he said, "If the first thing we want is real local telephone competition, we should demand just that, and not a bunch of complicated regulations theoretically designed to achieve competition." (Statement to the Senate Judiciary Committee Subcommittee on Antitrust, Monopolies, \& Business Rights, September 20, 1994, p. 2.)
} 
permit joint telecommunications network planning, design, and implementation among telecommunications carriers, cable television companies, railroads, and electric, gas, water, and other utilities in the same geographic area.

According to the committee report, Sec. 229 had the following aim :

There are many utilities and cable television companies who have rights-of-way, unused or underutilized telecommunications infrastructure in the same geographic area where infrastructure development for universal service will be planned. These entities might be willing to participate in the development of this telecommunications infrastructure and thereby reduce the overall cost of universal service, as compared to building new or dedicated infrastructure, especially in rural areas. ${ }^{72}$

So the Senate had begun (prior to the demise of S. 1822) to recognize one way utilities could contribute wherewithal to build advanced telecommunications in. general and, by assuring universal service, "especially in rural areas."

\subsection{Fitting Utilities into Universal Service}

The network planning initiative in the Senate was a modification to the "grand design"73 that could hasten achieving universal service and stabilize the evolution of networks along lines that few would have anticipated when the NII began years ago. Until Sec. 229 was added, the drive to modernize networks concentrated entirely on "facilities-based competition" between two wires as the model for local service--a strategy that would necessitate building plants that could be duplicative and redundant and yet might provide only incomplete coverage. ${ }^{74}$ Moreover, competitive infrastructure would spawn vertical integration between transport and services of the sort forecast by John Malone of cable giant TCI as constituting an "oligopoly."75

The possibility that such competing facilities could be built more surely if a well-heeled third party-the electric utility-joined in would fortify the model against its economic fragility; but maybe an even better model might emerge if the utility alone were to build the infrastructure, to be used by mutually competitive telecommunications and information providers without the utility itself undertaking to serve customers-precisely what the new legislative category "infrastructure provider" would encompass.

\footnotetext{
${ }^{72}$ Report on Communications Act of 1994, Senate Committee on Commerce, Science, and Transportation, September 14, 1994, p. 50.

${ }^{73}$ The term "grand design" is the way a recent New York Times editorial referred to the strategy of allowing local Bell telephone companies into long-distance and information services, while allowing long-distance and cable companies-and, as we have seen, utilities too-into local telecommunications: "The grand design would empower disgruntled customers to do more than curse rotten service from phone and cable companies: they could switch providers." (New York Times, July 6, 1994, p. A18.)

${ }^{74}$ The dilemma of redundant facilities may have been prefigured by the failure of the brief competitive era in telephony, which ended about 1920. In 1919, a Missouri Public Service Commission reported:

Competition between public service corporations was in vogue for many years as the proper method of securing the best results for the public. ... The consensus of modern opinion, however, is that competition has failed to bring the result desired. (Johnson County Home Telephone Company, $18 \mathrm{Mo}$. PSCR 637 [cited in Stone, Wrong Number, pp. 44-45].)

${ }^{75}$ His January 25, 1994, speech to the Center for Strategic and International Studies in Washington is reported in Telecommunications Reports, January 3.., 1994.
} 
Starting down this road of adaptation could have breathtaking consequences for the speed and scale by which the NII would move to completion, as well as for maximizing competition among providers of information services over a common infrastructure. Such services could be measurably freer than via an "oligopoly" because they would not be linked to the capital burdens of building competitive facilities and because the infrastructure provider would have financial incentives to encourage maximum use of its infrastructure.

As is well known by now, the unique potential contributions of electric utilities to building modern telecommunications lie in the ability of telecommunications to save energy and thereby to pay for itself, beginning virtually immediately. ${ }^{76}$ Significantly, electric utilities serve a portion of the U.S. residential population that is one percentage point greater than telephone companies-95\%, compared to $94 \%$-and more than $30 \%$ greater than cable television. ${ }^{77}$ Energy savings believed attainable from telecommunications could significantly reduce the average residential consumer's electricity bill-which is more than $\$ 700 /$ house/year ${ }^{78}$-creating a pool of capital for building telecommunications infrastructure with far greater speed and certainty than the untried consumer services such as video-on-demand and interactive entertainment favored by the incumbents and thus far assumed to be the only way to finance a two-wire world.

Once potential contributions of such magnitude and timeliness came to be recognized, it has become impossible to overlook them, though so far neither the cable nor telephone industries have been eager to find ways to tap into these socially and economically beneficial applications as a source of capital for building their own facilities or maximizing consumer benefits. ${ }^{79}$ The incumbents have been more noticeably concerned, and understandably so, with the possibility that electric utilities, fueled by monopoly revenues thrown off from efficiencies in the electric business, could vigorously compete against the incumbents in their own traditional fields of business. ${ }^{80}$ Until the addition of Sec. 229 to the Senate bill, there was little indication that utilities would be able to find a way to fit easily into the grand design; they would have to fight their way in-a prospect daunting to all.

Entergy's well-known project in Chenal Valley, Arkansas, has set off alarm bells as well as cheers. Initially, Entergy's Least Cost Integrated Resource Plan-

\footnotetext{
${ }^{76}$ According to Billy Ray, the superintendent of the electric plant board in Glasgow, Kentucky, installing a \$500/customer telecommunications system would achieve an average peak demand reduction per customer of $2-3 \mathrm{~kW}$. "That would equate to installing new capacity at a rate of $\$ 167-\$ 250$ per $\mathrm{kW}$." Put another way, "We built out the beginnings of the NII-and at a cost of less than one-tenth of constructing new generating capacity." (Testimony to the Department of Commerce Hearings on the NII, July 12, 1994, pp. 3, 4.)

${ }^{77}$ Sources: Statistical Abstract of the United States-1993, pp. 561 and 563 (telephone: $93.9 \%$ ), and pp. 589 and 728 (electric: $95.0 \%$ ); and Paul Kagan, Marketing New Media (December 14, 1992), p. 4 (cable: 62\%).

78 'The average U.S. residential electric bill for 1991 was $\$ 777$ or [thus we are estimating] about $\$ 39$ per residence/year [in savings from telecommunications]." (Quote adapted from "Supply and Demand of Electric Power and the NII," in The Information Infrastructure: Reaching Society's Goals, Report of the Information Infrastructure Task Force Committee on Applications and Technology, National Institute of Standards and Technology, U.S. Department of Commerce, September 1994, p. 29.)

${ }^{79} \mathrm{~A}$ partial exception is the limited demonstration by TCI, PG\&E, and Microsoft about to get under way in 1,000 homes in Walnut Creek, California, and elsewhere, with the power company a provider of information services rather than a facilities builder. See “A Powerful Pitch," San Jose Mercury News, July 11, 1994, p. 1D.

${ }^{80}$ This concern for the unbounded capabilities of the electric utilities as head-to-head competitors in telecommunications has been manifest in regulatory proceedings before the New Orleans City Council involving Entergy's Customer-Controlled Load Management (CCLM) project; the proceedings are cited on the next page and in the July 24, 1994, hearing of the Energy and Telecommunications Subcommittees of the U.S. House Committee on Energy and Commerce, where BellSouth testified to rebut the efforts of registered holding companies (such as Entergy) to free themselves from SEC regulation.
} 
Three Year Action Plan, which it filed on December 1, 1992, with PUCs in Arkansas, Louisiana, Mississippi, and in the City of New Orleans, would have positioned the power company to serve a total of 442,090 customers eventually with its CCLM technology.

These electric customers, who would voluntarily choose the service just because it enabled them to reduce their electric bills, would constitute $30 \%$ of its highest-income customers and $60 \%$ of its middle-income customers. For these customers, electric bills would come down considerably, but still additional savings would be thrown off that the power company could channel into building the telecommunications facilities that would make it all happen. ${ }^{81}$

The alarm came in New Orleans, a city served by Entergy and embraced within. its Three Year Action Plan, where local regulators (the City Council directly regulates utilities in New Orleans) were quick to challenge Entergy's initiative for its technical and regulatory uncertainties. (Relevant too were competitive considerations prompted by cable and telephone incumbents.) There was suspicion that Entergy was preparing a classic regulatory scam, aiming to put the entire cost of its telecommunications facilities in electric rate-base and the entire nonelectric revenues "below the line"; i.e., loading all the costs on electric ratepayers and paying all the profits to electric shareholders.

The particular assertion was made in challenging Entergy that the electricity-saving and -control applications for its intended fiber/coax system would. use only $2 \%$ of bandwidth, which would leave $98 \%$ available for nonutility purposes. Thus the ratepayers would be paying to build the entire system, but Entergy would be capturing a windfall in control over excess capacity.

The power company justified rate-basing all its costs by simply emphasizing that "the appropriate test is whether benefits exceed costs, and they do... . [T] $T$ C CLM program passed the screening tests. That in itself should justify the CCLMI program." 82 But Entergy's intentions with respect to using and accounting for: the excess capacity were never stated clearly. When the city opened up hearings at the end of 1993, Entergy was caught flat-footed; its plans for New Orleans had not yet jelled, ${ }^{83}$ and its lack of specific preparations cast the company in a disingenuous light.

As the proceedings grew quarrelsome and threatened to produce a negative result, Entergy chose to head off a losing fight, for now. The power company proposed to site a 1,600-unit two-year demonstration of CCLM costing $\$ 10$ million in New Orleans and to pay for it entirely out of corporate funds. ${ }^{84}$

The company implied it might seek rate-base treatment for costs later on, when it could approach the issues of cost and profit after having proved the

\footnotetext{
${ }^{81}$ According to Entergy's most recent figures, its (20-year) electricity benefits would be $\$ 1845 /$ house: "avoided generating capacity" $\$ 653$; "avoided fuel" $\$ 338$; "third-party cost sharing" $\$ 300$; "conservation savings" $\$ 214$; "energy loss savings" $\$ 82$; "productivity savings: remote on/off" \$81; "productivity savings: remote meter reading" \$63; "avoided O[perations] \& M[aintenance]" $\$ 52 ;$ "productivity savings: DSM evaluation and measurement" $\$ 59$; and "other benefits related to distribution automation" \$2. Its (20-year) telecomminnications and computing costs to serve each of these selected customers would be \$1172/house: "infrastructure" \$250; "hardware" \$600; "O[perations] \& M[aintenance]" \$310; and "Miscellaneous" \$10. The resulting benefit/cost ratio $(\$ 1845 / \$ 1172)$ of 1.57 would ensure that the deployment succeeds for selected upper-income customers whose benefits and costs would be in this ratio. See The PowerView System: Two-Way Communications for Electric Utility Applications, Edison Electric Institute (1994), pp. 17-21.

${ }^{82}$ Rebuttal Testimony of Michael F. Niggli on behalf of New Orleans Public Service, Inc., October 13, 1993, p. 13.

${ }^{83}$ The only real activity in the CCLM project was taking place in the Chenal Valley, Arkansas, test.

84 "Joint Motion to Dismiss Without Prejudice or, in the Alternative, to Withdraw the Customer-Controlled Load Management Program," filed by NOPSI and LP\&L in New Orleans City Council, Docket Nos. UD-92-2A and UD-92-2B, January 18, 1994.
} 
project's value to the public. In June, Entergy's New Orleans subsidiaries moved to dampen the controversy further by applying for a temporary municipal franchise to conduct its tests, thereby also deferring until later determination the question of whether it already possesses long-range rights to build telecommunications facilities and deliver telecommunications services in the city. ${ }^{85}$

\subsection{Utility Rate Incentives Can Assure Universal Service}

The writer believes that Entergy's stumbling start in New Orleans reveals both a need and an opportunity now for electric utilities to close down some of their "options" in telecommunications and lay firm claims to having unique capabilities to achieve universal telecommunications service. ${ }^{86}$

Before the New Orleans City Council, Entergy illuminated the regulatory options open to the city, in terms that the city came to suspect masked Entergy's real intent to appropriate the value of excess capacity to itself (if only because of the pendency of telecommunications reform legislation that could lighten Entergy's SEC burdens). Entergy's witness ${ }^{87}$ testified:

In addition, ratepayers will benefit from the tremendous additional capacity available in the fiber/coaxial broadband network to be installed. This is an unquantified, yet, very real and significant benefit. A by-product of the broadband network proposed for DSM is the enormous additional capacity available through that network for other uses, such as telecommunications, cable television service, data transmission, et cetera. It should be noted that the Public Utility Holding Company Act of 1935 does not permit Entergy to become a telephone company. The sale to, or use by, other companies of this excess capacity in the fiber/coax network may generate additional revenue. This revenue presents to the Council a number of options. Either the "cost" to install CCLM can be reduced by allowing other companies to participate in the fiber/coax network, or the revenue from excess capacity can be used to reduce electric rates. The extent to which other companies participate will determine the extent to which the cost to ratepayers may be reduced. If, for example, the Council chose to "keep" $100 \%$ of the investment in the fiber/coax network for its ratepayers, the Companies would install the system and would reflect $100 \%$ of that cost in rates. As the Companies sold the rights to excess capacity in that network, the Council could "capture" for ratepayers revenue from such sales by imputing that revenue to the Companies' revenue requirement used for rate-making purposes.

\footnotetext{
85“Joint Application for Limited Franchise for Use of Public Ways to Construct and Operate a Fiberoptic Network and for Approval of an Experimental Time-of-Use Rate Schedule," filed by NOPSI and LP\&L in New Orleans City Council, Docket UD-941, June 3, 1994.

${ }^{86}$ Such shrewd repositioning has been done before, with spectacular results, in a not-dissimilar circumstance where universal service was also becoming a defining public concern. Around World War I, AT\&T's president Theodore N. Vail fended off antitrust enforcement against his company by deftly identifying AT\&T with the public interest:

[AT\&T] promised to improve equipment and operating procedures and to continue expansion into uneconomic, sparsely settled, and difficult-to-reach territories. Most importantly, ATET committed itself to attaining universal service, so that virtually everyone who desired a telephone could have one and could communicate with anyone else. Obviously, the public utility commissions were expected to regulate telephone pricing so that subsidy flows could allow these goals to be achieved. (Stone, Wrong Number [1989], p. 47 [emphasis added].)

${ }^{87}$ Rebuttal testimony of Michael R. Niggli on behalf of NOPSI, October 13, 1993. The ensuing quotation is at pp. 13-14 of the official transcript.
} 
This would lower the bills of all electric ratepayers in the [City of New Orleans] jurisdiction. This might produce a greater reduction in electric bills than any other DSM program.

If, on the other hand, the Council believed that electric ratepayers should not be asked to bear the "risk" of a fiber/coax network, it could authorize the Companies to "sell-off" some or all of the rights to the excess fiber/coax capacity, so that only the cost of that portion of the fiber/coax network needed for DSM would be borne by the ratepayers. In that case, the Council would put in rates only the CCLM costs needed for DSM; thereby limiting the burden borne by the Companies' ratepayers, while increasing significantly the benefit/cost ratio for CCLM. The companies purchasing the rights to the excess fiber/coax capacity would then bear the entire risks, and rewards, of the excess capacity they purchased. ${ }^{88}$

The foregoing fairly states the broad options open to the investor-owned utility and the regulator in accounting for the costs of telecommunications infrastructure built for energy-management purposes but usable more widely: Either put the whole facility in the utility's "rate-base" 89 and use any revenues gained from the excess capacity to reduce the utility's "revenue requirement," 90 or put some lesser amount into rate-base - such as the percentage of bandwidth actually "used and useful" for energy management ${ }^{91}$ —and allow the utility's shareholders to "capture" most revenue from excess capacity.

In these ways, the ratepayer would not be subsidizing the entrepreneur, but only paying for what he or she needs and uses. As a practical matter, however, enormous benefits will flow to the ratepayer from the utility's initiative, which the utility will naturally and fairly feel entitled to share. Herein lies the political problem facing the regulator in allowing the utility to profit from its windfall at the ratepayer's expense. Regulators might ultimately be willing to bend their traditional rules of prudence a bit-as they have from time to time for utility investments in DSM ${ }^{92}$ and, somewhat analogously, for excess capacity in nuclear plants the regulators are anxious to see written off ${ }^{93}$ - but their flexibility is circumscribed by the likely antagonism from the utility's telephone company

\footnotetext{
${ }^{88}$ All of which was true and illuminating, as of the time it was uttered. Nevertheless, the subsequent efforts of Entergy and other registered holding companies to secure exemption from the Public Utility Holding Company Act, preempting from state and local regulation, would remove that Ant as a protection against NOPSI "capturing" excess bandwidth for itself.

${ }^{89}$ "Rate-base" is the capital accoun: with respect to which the investor-owned utility is entitled to earn a "reasonable rate of return." Specifically:

For ratemaking purposes, the rate base represents the total value of a utility's property-plant and equipment, materials and supplies, and fuel-stock or gas-storage inventories-plus an allowance for cash working capital minus depreciation, amortization, and deferred tax reserves. (Introduction to Public Utility Accounting, American Gas Association [Reeser], p. 47.)

$90^{\prime \prime}$ Revenue requirement" is the gross revenue the utility needs to receive from customers' bills to pay a reasonable return on rate-base. Ibid., p. 55. If the utility gets money from some other source that "belongs to the ratepayers," proper accounting procedures would credit that money against the utility's "revenue requirement."

${ }^{91}$ Conservatively, given the transformation in utility distribution that may occur, bandwidth far larger than 2 percent may prove to be "used and useful" to the utility.

${ }^{92}$ Rate-basing of DSM expenditures is now allowed in almost half the states (specifically, 24 states), as a consequence of statutes and/or regulatory decisions and rules. (Integrated Resource Planning in the States: 1994 Sourcebook, Edison Electric Institute, Table 10.)

${ }^{93}$ Settlements allowing rate-basing of unamortized costs of abandoned nuclear plants have been allowed, for example, in Washington to terminate the WPPSS imbroglio (Washington Water Power Company, 81 PUR 4th 229 [1987]), and by the FERC to bring an end to the similar problems of Seabrook (Maine Public Service Company, 46 FERC Sec. 61,183, 103 PUR 4th 43 [1989]). However, acceptance into rate-base was denied in North Carolina when a court found that the PUC there had "no equitable powers." (North Carolina Utilities Commission v. Thornburg, 107 PUR 4th 432, 385 SE2d 468 [1989].)
} 
rival, which itself is seeking liberal accounting treatment from the same regulators so it too can modernize its existing plant by installing fiber-optic technologies.

The challenge of ensuring universal service is one very potent reason why these same regulators and electric utilities have reason to try to get together and slice up the windfall of excess capacity. It is notable that in all of Entergy's regulatory dealings, with local regulators and the SEC, no commitments have been made to deploy CCLM services beyond the 400,000 + vaguely mentioned, all of whom would be voluntary adherents, since installation for them would be "costjustified"-presumably on a house-by-house basis. But the large proportion of the ratepayers not entitled to anticipate such a high "benefit/cost ratio" (see note 81 )-about 60 percent of all customers-will still need and benefit from (if only to a lesser degree) the energy-saving opportunities made possible by advanced telecommunications. And the same is surely true for institutions such as schools and medical facilities that fall outside the residential calculus but still are especially important claimants for telecommunications services, and energy savings too.

Regulators can, and should, allow electric utilities ${ }^{94}$ incentives to secure the rapid build-out of information infrastructure. ${ }^{95}$ Specifically, conflicts like that in New Orleans could be resolved with the utility benefiting substantially from the excess capacity of its load-management-initiated telecommunications system, if the utility agrees to measured commitments to the regulator to construct facilities-and to provide services too ${ }^{96}$ - on a universal basis.

\subsection{Telecommunications Reform Via a New Regulatory Compact}

Enactment into law of telecommunications reform legislation resembling the bills that were in Congress in 1994 would have the effect of enabling a new regulatory compact to emerge that affords electric utilities rate incentives in exchange for their contributions to achieve universal service. It would remain only for utilities to seek to shape their plans to fit the need, ${ }^{97}$ and to take advan-

\footnotetext{
${ }^{94}$ Were the utility not to make available the benefits of remote, real-time sales and purchases of electricity to all, its customers would eventually bring charges of unfair discrimination potentially violating its utility obligations. According to the leading treatise: "But the accepted rule clearly is that 'a utility may charge but one rate for a particular service, and any discrimination between customers as to the rate charged for the same service under like conditions is improper' [citing FER Lazarus \& Co. v. PUC, 122 NE2d 783, 786 (Ohio, 1954)]." (1 Priest, Principles of Public Utility Regulation, p. 288.) Hence a utility's introduction of new technology must be made both fairly and deliberately and with its own requisites for providing universal service in mind.

${ }^{95}$ Even more than IOUs, municipal utilities will be sensitive to public interests in achieving universal service, and will eventually warm to their traditional "yardstick" role, especially if federal legislative guidelines on universal service emerge. According to one municipal leader, Billy Ray of Glasgow, Kentucky: “This 'yardstick' has served the people of this country well in the provision of electric power. The same model will work just as well in the twenty-first century for the provision of high technology telecommunications." (Testimony before the Subcommittee on Communications, Senate Commerce, Science and Transportation Committee, September 8, 1993, p. 4.)

${ }^{96}$ Because the utility needs to communicate with its meters, for instance, it has legitimate, economically significant concerns that transcend merely building infrastructure. So the question of excess capacity relates not just to infrastructure but also to information services. Antitrust policy may suggest some pause in how far the utility can be allowed to exploit these natural synergies, paid for by ratepayers and to the potential disadvantage of competitors, but it is very clear that the utility can easily get its foot in the door in both telecommunications and information businesses. Given such opportunities, utilities would be as ill-advised to overreach as they would be to fail to reach out fast enough to grasp some of these opportunities.

${ }^{97}$ The notion of a regulatory compact between regulated utilities and their regulators was invented, essentially out of whole cloth, during the Progressive Era, when PUCs took on supervisory duties vis-à-vis monopoly providers of public services. Thus, at a critical time in [AT\&T]'s history [Theodore J. Vail] recognized the benefits of close public utility regulation through regulatory commissions, in exchange for which AT\&T and its licensees obligated themselves to such
} 
tage of the opportunities being offered them by the Administration and Congress. So far, most utilities are keeping their options open. They and their regulators have not approached utility telecommunications as a responsibilityjust as a business opportunity to be taken or left as they wish.

As indicated previously, the mandate to achieve universal service is becoming clear for providers of telecommunications. Whatever procedure for univer:sal telecommunications service is finally adopted by Congress and regulators, a variety of expedients is already in view, and one more should be welconed, given the intensity of public concern and the undeniable fact that better solutions still need to be found. Thus the Senate bill specified that "[e]very teleconmunications carrier ... shall contribute to the preservation and advancement of universal service (Sec. 102(c)," without being definitive as to what the contributions might be.

With the broad mandate of these and likely successor bills, there is no reason why the lists of possible expedients open to state PUCs could not also include the option of rate incentives to electric utilities too. For example, it would be possible to derive specific authority to make such incentives available to "infuastructure providers" whose identity is now recognized in Sec. 229 of the Senate bill, were that or a similar provision to pass. Moreover, the process of "network planning," also in the Senate bill, would give utilities a seat at the table in procedures envisaged for every state, early enough to ensure that specific arrangements to share infrastructure could be coordinated by the state's PUC.

For the process to start now the utilities must acknowledge that they want to participate in building infrastructure or in some larger role (which encompasses building facilities) to assure service to the public on a basis that will be more truly universal than telephone and cable companies are so far ready to provide. In the next round of legislation, utilities might go so far as to seek out a public function as a "guarantor of universal service" - an initiative much like AT\&T's brilliantly successful strategy cited above.

The process of seeking regulatory incentives could be initiated either in national proceedings before the FCC or in approaches to individual state regulatory commissions. Depending on the detail with which states determine electric rate-making and telecommunications policies legislatively, some states may want to adopt specific statutes to encourage utilities in the context of state telecommunications plans, ${ }^{98}$ but in other states PUCs might proceed under the mandates of their existing authorities over electric and telecommunications services.

In any event, when utilities eventually do seek cost recovery in rates for teleconamunications facilities they have built, strong support for generous treatment of utility initiatives will derive from the national policy favoring universal service that is likely to be a prominent concern in new federal telecornmunications legislation.

goals as universal service and technological progressiveness. AT\&T, in a word, had a private agenda wrapped in a conception of the public irterest. But unlike later participants in the telecommunications industry, its private interest was in the interest of the general public. (Stone, Wrong Number, op. cit., p. 44.)

${ }^{98}$ A requirement for states to prepare such a "State Telecommunications Modernization Plan" has already been enacted by Congress, as a part of the Rural Electrilication Loan Restructuring Act of 1993 (P.L. 103-129), which, though concerned directly with REA telephone lending, has an unrestricted reach. 


\section{Chapter 4}

\section{A NEW OPTION FOR TELECOMMUNICATIONS REFORM}

Most of this study was written before the 103rd Congress adjourned, by which time it had become clear that telecommunications reform would not be enacted in 1994 and some new effort would have to be mounted in 1995. In the aftermath of the failure, there have been many post-mortems, and there doubtless will be even more before another legislative round is done. One perspective that needs to be explored is that electric utilities can play an even larger and more central role than that scripted for them in the 1994 legislative proposals.

What was proposed in 1994? And what greater role would be useful to consider now?

Both this Administration and the preceding one espoused "two-wire" scenarios that anoint competing telephone and cable companies to raise private capital. This design for a national program to raise the huge capital needed for advanced telecommunications facilities presumes that the public would eagerly spring to buy a mammoth menu of information-predominately entertainmentserved via rival networks that John Malone of cable giant TCI has called "an oligopoly." 99

Yet two telecommunications wires to the home would double the costs and split the revenues, an ominous mismatch that has already warned of slowed deployment, business failures, and new monopolies. ${ }^{100}$ Unavoidably, competitive networks would also tend to cream-skim affluent and more easily served customers, guaranteeing unequal service to large segments of the public. Such were the shoals the 103rd Congress tried and failed to navigate.

One bright spot in 1994 was that both the Administration and Congress recognized electric utilities as vital to the mix of potential telecommunications providers. In January, Vice President Gore asked Congress to enable power companies to offer telecommunications just like telephone companies. Bills in both the House and Senate would have opened that door.

Senate Bill 1822, which was approved by the Senate Commerce Committee but failed to come to the floor, added a rider that could now move closer to the heart of a new bill: electric utilities could build facilities as "infrastructure providers" that other entities-"telecommunications carriers"-would use to serve customers. Significantly, infrastructure providers themselves would not be telecommunications carriers.

\footnotetext{
${ }^{99}$ See Telecommunications Reports, January 31, 1994.

${ }^{100}$ Even before the notable coming apart of the proposed Bell Atlantic-TCI merger, financial analysts were expressing doubts about what some were calling "a destructively competitive 'two-wire world,' where phone and cable companies would spend billions of dollars to provide high-capacity networks that basically duplicated each other." See Anthony Ramirez, "Reappraising the Bell Atlantic-Tele-Communications Merger," New York Times, February 1, 1994, p. D8.
} 
This option, that utilities become facilities-builders only, was intended for rural rnarkets where competition would least likely produce universal service. But a shared infrastructure ought to do just as well in cities or, even better, to meet refocused national needs - to scale back the capital demands required for dual advanced networks, to assure that coverage is truly complete, and to create market conditions that can promote full competition in telecommunications and information services, unlike the high prices and limited access of an oligopoly.

Fhone companies, cable companies, and anyone else could rent space on utilities' common infrastructure. Since modern fiber-optics can carry a gigabit of information, there will be so much capacity that one wire will be sufficient to assure competition in services. Access should never be at a premium; the more on board, the merrier the trip will be.

In filling this unique crossover role, electric utilities should retain some scope t:o provide their own information services to and from the home to manage electricity supply and demand. Otherwise, the infrastructure that utilities build and manage would function much like common carriers do today. AT\&T's history of successfully building telephone networks earlier this century teaches that some judicious reduction in the competitive field may be essential to assure that tomorrow's broadband networks attain economic efficiency, open access, and uriversal coverage.

The power companies could pay for common infrastructure out of energy savings. Despite regulators' predictable hesitation (Public Utilities Commissions also regulate telephones), the task of "protecting energy ratepayers" need not be much of a barrier; simply because energy savings could more than pay for networks, power companies would not themselves be telecommunications competitors, and anyway neither telephone nor cable companies are plausibly seeking energy savings for consumers.

A. very timely initiative now, however, would be for Congress to clarify that utilities could earn a profit from telecommunications comparable to what they can eas'n from investing in energy plants. Electric utilities will be able to demonstrate that shifting energy demand via advanced, two-way telecommunications will be their most potent energy-saving investment of all.

Thus telephone companies may have forfeited their claim to leadership in building the information superhighway when they backed away from telecornmunications reform. They also enabled the nation-with critical help from electric utilities-to fashion new and better options. 